\title{
New data on vibrational calling signals of Fulgoroidea (Homoptera: Auchenorrhyncha) from the Asian part of Palaearctic with new records of three species of Cixiidae
}

\section{Новые данные о вибрационных призывных сигналах Fulgoroidea (Homoptera: Auchenorrhyncha) из азиатской части Палеарктики и новые находки трех видов Cixiidae}

\author{
D.Yu. Tishechkin \\ A.Ю. Тишечкин
}

Department of Entomology, Faculty of Biology, M.V. Lomonosov Moscow State University, Vorobyevy Gory, Moscow 119234, Russia. Email: macropsis@yandex.ru

Кафедра энтомологии Биологического факультета Московского государственного университета имени М.В. Ломоносова, Воробьёвы Горы, Москва 119234, Россия.

KEY WORDS: Homoptera, Auchenorrhyncha, Fulgoroidea, Cixiidae, Dictyopharidae, Meenoplidae, Caliscelidae, vibrational communication, vibrational signals, new records.

КЛЮЧЕВЫЕ СЛОВА: Homoptera, Auchenorrhyncha, Fulgoroidea, Cixiidae, Dictyopharidae, Meenoplidae, Caliscelidae, вибрационная коммуникация, вибрационные сигналы, новые находки.

ABSTRACT. Calling signals of three species of Delphacidae (Kelisiinae and Delphacinae), 13 species of Cixiidae, one species of Meenoplidae, two species of Dictyopharidae (Dictyopharinae and Orgeriinae), and two species of Caliscelidae from the Asian part of Palaearctic are described and illustrated by oscillograms and sonograms. Species of Cixiidae, Meenoplidae, and Dictyopharidae produce simple calling signals consisting of uniform short pulses; in Delphacidae and Caliscelidae signals have much more complex temporal and frequency pattern. Signal recordings of Cixius sibiricus, C. granulatus, and Reptalus narynensis were made far outside their known ranges; for these species drawings of male genitalia of specimens from new localities are given.

РЕЗЮМЕ. Описаны призывные сигналы 3 видов Delphacidae (Kelisiinae и Delphacinae), 13 видов Cixiidae, 1 вида Meenoplidae, 2 видов Dictyopharidae (Dictyopharinae и Orgeriinae) и 2 видов Caliscelidae из азиатской части Палеарктики, приведены их осциллограммы и сонограммы. Представители Cixiidae, Meenoplidae и Dictyopharidae издают сигналы со сравнительно простым временным рисунком, состоящие из коротких однотипных пульсов; сигналы Delphacidae и Caliscelidae имеют гораздо более сложную временную и частотную структуру. Записи сигналов Cixius sibiricus, C. granulatus и Reptalus narynensis были сделаны в точках, лежащих за пределами их известных ареалов; для этих видов приведены рисунки гениталий самцов из новых местонахождений.

\section{Introduction}

Delphacinae (Homoptera: Auchenorrhyncha: Delphacidae) were the first objects of Fulgoroidea bioacoustics. Nilaparvata lugens (Stål, 1854) was the first species not only of Delphacinae, but also of all small Auchenorrhyncha for which was proved conclusively, that its acoustic signals transmit via substrate i.e. leaves and stems of host plants [Ichikawa, Ishii, 1974]. Investigation of signals of Javesella Fennah, 1963, Muellerianella Wagner, 1963, Ribautodelphax Wagner, 1963, Chloriona Fieber, 1866, and species from some other genera showed that the calling signals in this subfamily for the most part are rather complex phrases consisting of several different elements [de Vrijer, 1984, 1986; Booij, 1982; den Bieman, 1986, 1987; Strübing, Rollenhagen, 1988; de Winter, Rollenhagen, 1990; Gillham, de Vrijer, 1995].

Information on signals of other Fulgoroidea in those years was very scarce. Description of vibrational signals and mating behaviour of Dictyophara europaea (Linnaeus, 1767) (Homoptera: Dictyopharidae) was published by Strübing [1977]. Vibrational signals and mating behaviour in a number of peculiar species of cave-dwelling Cixiidae (Homoptera) were described by Hoch and co-authors [Howarth et al., 1990; Hoch, Howarth, 1993; Hoch, Wessel, 2006]. In species from both families signals consist of short simple uniform pulses, which can be grouped into single succession (syllable) either arranged in several trains of equal or different duration. Thus, their temporal pattern is much more simple, than in Delphacidae. In Cixiidae, this 
phenomenon seemed to be the part of general reduction trends usually occurring in cave-dwelling organisms.

Later, three papers on vibrational signals of Fulgoroidea from Russia and adjacent territories were published [Tishechkin, 1997, 1998, 2003]. The number of families and subfamilies studied increased significantly; calling signals of Derbidae, Issidae, Caliscelidae (Caliscelinae and Ommatidiotinae), Tropiduchidae, Kelisiinae (Delphacidae) and Orgeriinae (Dictyopharidae) were described for the first time. Surprisingly, it was found that simple calling signals consisting of uniform short pulses are not the exception but rather the rule in Fulgoroidea. Only in Delphacidae and Caliscelidae calling signals are complex, sometimes very long and variable phrases.

Similarity of signal temporal pattern in different species of Fulgoroidea is not a rare case. First, in congeneric species calling signals sometimes are almost indistinguishable. Three species from the genus Cedusa Fowler, 1904 (Derbidae) and two closely related species of Reptalus Emeljanov, 1971 (Cixiidae) can be mentioned as examples [Tishechkin, 2008; Emelyanov, Tishechkin, 2012]. Second, species from different genera of Delphacidae quite often produce similar signals; in fact, signals of a considerable part of species studied can be attributed to one of several main types. Third, simple trains of pulses typical for many Cixiidae, Issidae and Dictyopharidae occasionally are similar even in species from different families. Anyway, in all cases the similarity of signal pattern occurs in acoustically isolated species occupying different communication cannels i.e. in allopatric forms, in species dwelling in different plant communities, etc. [Tishechkin, 2008].

Recently, several new papers on vibrational signals of Fulgoroidea were published.

Comprehensive study of vibrational communication of Metcalfa pruinosa (Say, 1830) (Homoptera: Flatidae) provided first data on signals of Flatidae [Virant-Doberlet, Žežlina, 2007]. It was found that the signals of this species consist of uniform short pulses as in most other fulgoroid families. It is particularly remarkable that this species has nocturnal acoustic activity in contrast to most other small Auchenorrhyncha.

Detailed investigation of mating behaviour of Hyalesthes obsoletus Signoret, 1865 (Cixiidae) was performed by Mazzoni et al. [2010].

Data on vibrational signals of three species of Cixiidae were published by Hoch and co-authors [Hoch et al., 2011, 2013; Kunz et al., 2014]. Although the number of studied species increased only slightly, extensive study of their biology and mating behaviour is of great interest. In particular, it was shown that one species, Apartus michalki (Wagner, 1948) has the only rather short peak of the mating activity in the evening [Kunz et al., 2014]. Another species studied, Celebenna thomarosa Hoch et Wessel, 2011 belongs to the tribe Bennini; this was the first species of this tribe, which signals were studied [Hoch et al., 2011].

The aim of the present paper is to provide a new data on the diversity (or, rather, uniformity) of calling signals of Fulgoroidea. All recordings were made during expeditions to Lower Volga Region, Central Asia, South Siberia and the Russian Far East. On the one hand, this made it impossible to study mating behaviour including female reply signals, but on the other, it allowed to obtain signal recordings of some species not available for laboratory studies.

Signal recordings of three species of Cixiidae were made far outside their known ranges. For these species drawings of male genitalia are given to illustrate our interpretations of these forms and to provide new data on the variability of penis shape.

\section{Material and methods}

Planthopper vibrational signals were recorded by means of portable recording equipment consisting of a piezocrystal gramophone cartridge GZP-311 connected to the microphone input of a minidisk recorder Sony Walkman MZ-NH900 or a cassette recorder Elektronika302-1 (before 2005) via a custom-made matching amplifier. For recording a twig of host plant about $10-15 \mathrm{~cm}$ in length was attached to the cartridge by a rubber ring so that the cartridge needle touched the stem slightly. Then a nylon cage containing a male leafhopper was put on the twig. After a time, the male usually sat on the twig and started singing. All recording were made by the author.

Signal analysis was performed on a PC fitted with an analog/digital converter L-305 (L-Card Ltd., Russia). Oscillograms and sonograms of signals were produced with TurboLab 4.2 and Cool Edit Pro 2.1 software.

For elements of signal temporal pattern the following terms are used. Pulse is a brief elementary fragment of signal (or succession of sine waves) with rapid increase and subsequent decrease of amplitude, i.e. separated from similar fragments by amplitude minimums. Short fragments with more or less constant temporal pattern usually repeated with regular intervals and consisting of uniform or different pulses are referred to as syllables. Any more or less prolonged signal with complex pattern (e.g. succession of similar or different syllables, combination of several syllables and succession of pulses, etc.) is referred to as a phrase. Repetition period of pulses or syllables is an interval from the beginning of one syllable (pulse) to the beginning of the next one.

Specimens studied are deposited in the collection of the Zoological Museum of M.V. Lomonosov Moscow State University, digital signal recordings will be deposited in the Museum in the near future.

\section{Results}

\section{Family Delphacidae \\ Subfamily Kelisiinae \\ 1. Kelisia ribauti Wagner, 1938 \\ Figs 1-4.}

MATERIAL. Kyrgyzstan, Chatkal Mtn. Range, Sary-Chelekskiy Biosphere Nature Reserve, environs of Arkyt Village, 8.VII.2009. Calling signals of $1 \sigma^{7}$ recorded on disk at $20-21^{\circ} \mathrm{C}$.

REFERENCES TO SIGNALS. Tishechkin [2003], males from North Caucasus, North Ossetia. 

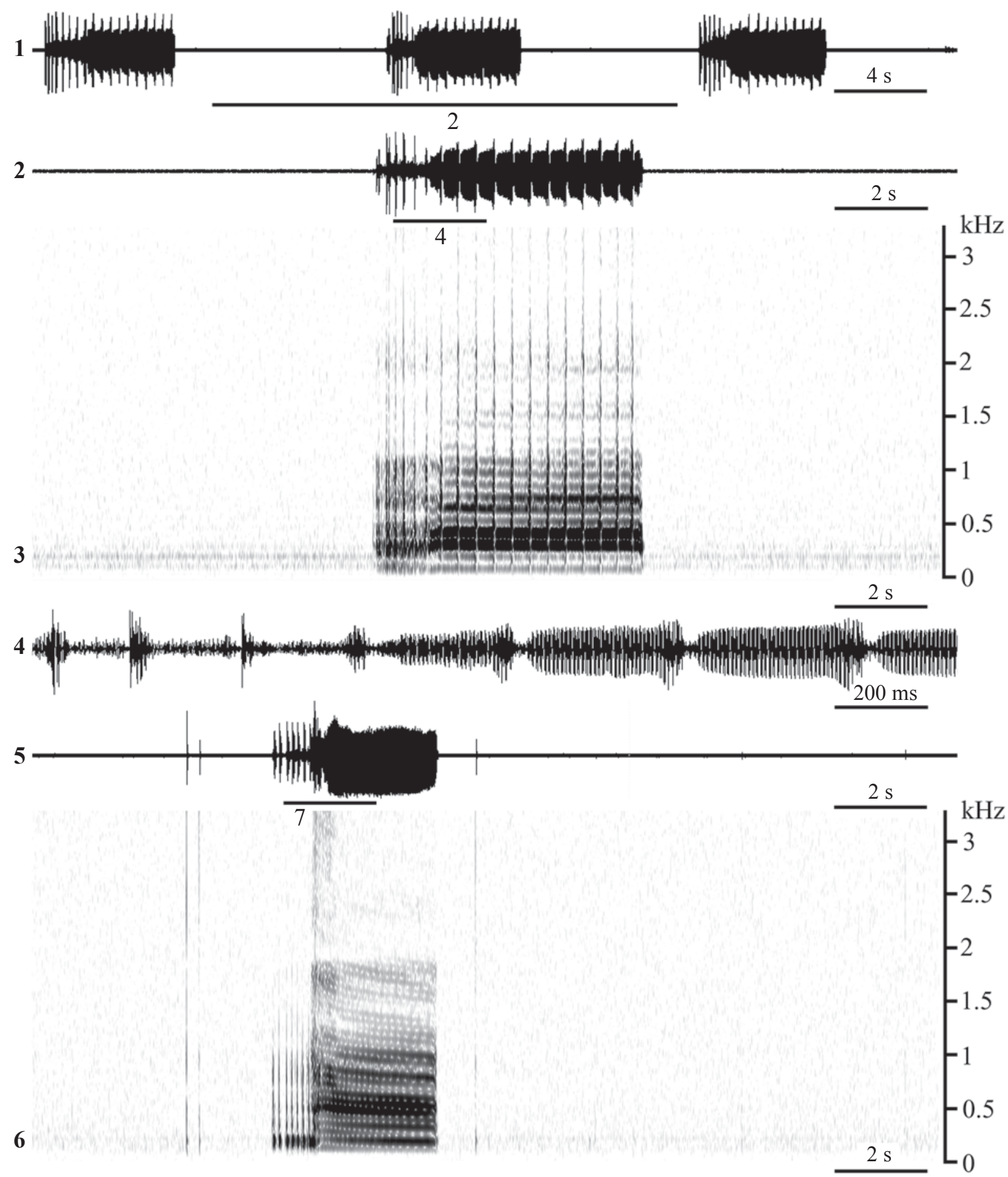

6

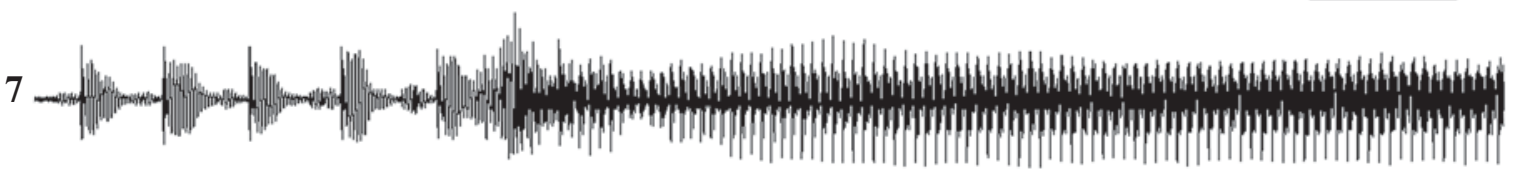

$200 \mathrm{~ms}$

Figs 1-7. Calling signals of Delphacidae: 1-4 - Kelisia ribauti; 5-7 - Laodelphax striatellus; 1, 4, 7 - oscillograms; 2-3 and 5-6 oscillogram and sonogram of the same signal. Faster oscillograms of the parts of signals indicated as "2", "4", and "7" are given under the same numbers.

Рис. 1-7. Призывные сигналы Delphacidae: 1-4 - Kelisia ribauti; 5-7 - Laodelphax striatellus; 1, 4, 7 - осциллограммы; 2-3 и 5-6 - осциллограмма и сонограмма одного и того же сигнала. Фрагменты сигналов, обозначенные цифрами "2", "4" и "7", представлены на осциллограммах под такими же номерами. 
SIGNALS. Calling signal consists of phrases following each other with pauses of about 8-9 s (Fig. 1). Each phrase consists of two different parts (Figs 2-4). The first part is a short train of high-amplitude pulses of rather variable shape. The second part is a long sequence of syllables. These two parts also differ distinctly in frequency spectra (Fig. 3).

COMPARATIVE NOTES. In males from North Ossetia phrases follow each other with about the same period as in male from Kyrgyzstan. However, the first part in their signals is much longer; for this reason pauses between phrases do not exceed 1-2 s. Also, in males from North Ossetia, the second part of a phrase sometimes is subdivided into two or three fragments separated by short gaps. Despite of these differences the signals of males from Caucasus and Central Asia retain common species-specific traits.

\section{Subfamily Delphacinae \\ 2. Laodelphax striatellus (Fallén, 1826)}

Figs 5-7.

MATERIAL. Kyrgyzstan, Chatkal Mtn. Range, Sary-Chelekskiy Biosphere Nature Reserve, environs of Arkyt Village, 3.VII.2009. Calling signals of $1 \mathrm{O}^{7}$ recorded on disk at $19-20^{\circ} \mathrm{C}$.

REFERENCES TO SIGNALS. Ichikawa [1976], males from Japan.

SIGNALS. Calling signal is a phrase lasting for about 4 $5 \mathrm{~s}$ and consisting of a short train of discrete pulses and a long monotonous fragment (Figs 5, 7). As in K. ribauti, two parts of signal differ in frequency spectra (Fig. 6).

COMPARATIVE NOTES. General schemes of signal temporal pattern in males from Central Asia and from Japan are similar.

\section{Unkanodes latespinosa (Dlabola, 1957)} Figs 8-15.

MATERIAL. Kyrgyzstan, Chatkal Mtn. Range, Sary-Chelekskiy Biosphere Nature Reserve, environs of Arkyt Village, Botriochloa ischaemum (L.) Keng on steppe slopes, 29.VI.2011. Calling signals of $5 \mathrm{O}^{7} \mathrm{O}^{7}$ recorded on disk at $22^{\circ} \mathrm{C}$.

SIGNALS. Calling signal is a phrase lasting from 1-1.5 to 4-5 s (Figs 8-11). Its main part is a train of pulses or syllables of various shapes. The last syllable ends with a monotonous fragment lasting for 150-300 ms (Figs 12-15).

$$
\begin{gathered}
\text { Family Cixiidae } \\
\text { Tribe Duiliini } \\
\text { 4. Duilius fasciatus (Horvath, 1894) } \\
\text { Figs 16-18. }
\end{gathered}
$$

MATERIAL. Lower Volga Region, Dosang Railway Station 60 $\mathrm{km}$ North of Astrakhan', Tamarix ramosissima Ledeb. in the floodplain of Akhtuba River, 3.VII.2010. Calling signals of $4 \mathrm{O}^{7} \mathrm{O}^{2}$ recorded on disk at $22^{\circ} \mathrm{C}$.

SIGNALS. Calling signal is a phrase lasting for about 10 $\mathrm{s}$ and consisting of uniform syllables (Figs 16, 18). The phrase begins quietly reaching the maximum amplitude at about the middle of its duration. Syllable repetition period varies from 180 to $230 \mathrm{~ms}$ at $22{ }^{\circ} \mathrm{C}$. In each syllable $8-12$ pulses can be discerned. Syllables from different parts of a song are similar in frequency spectra (Fig. 17).

\section{Tribe Cixiini}

5. Cixius sibiricus Emeljanov, 1979

Figs 19-21, 29-30.

MATERIAL. Extreme Southeast of Saratov Area, 2-3 km East of Ozinki Town, Artemisia abrotanum L. in the steppe near the pool, 1.VII.2004. Calling signals of $2 \sigma^{7} \sigma^{7}$ recorded on tape at $27^{\circ} \mathrm{C}$.
SIGNALS. Calling signal is a phrase lasting for 2.5-3.3 s and consisting of about 30-40 uniform syllables in our recordings (Figs 19-21). The phrase begins and ends quietly reaching the maximum amplitude in the middle of its duration. Syllable repetition period increases from $70-80 \mathrm{~ms}$ in the beginning to $110-120 \mathrm{~ms}$ in the end of a phrase at $27^{\circ} \mathrm{C}$. Each syllable consists of two pulses.

REMARK. This species is known from Yakutia, Central Kazakhstan and South Urals [Emelyanov, 2015]. At the present time the locality in Saratov Area is a westernmost record of this species. Drawings of penis of male from this locality are presented on Figs 29-30.

\section{Cixius granulatus Horvath, 1897}

Figs 22-25, 31-33.

MATERIAL. Kyrgyzstan, Turkestan Mtn. Range, environs of Katran Village, Layli-Mazar River $2-3 \mathrm{~km}$ upstream from the source of Lyaylyak River, Betula tianschanica Rupr., 23.VI.2016. Calling signals of $1 \mathrm{O}^{7}$ recorded on disk at $22^{\circ} \mathrm{C}$.

SIGNALS. Calling signal is a phrase lasting for $5.5-7.5 \mathrm{~s}$ and consisting of 12-14 uniform syllables in our recordings (Figs 22, 24-25). The phrase begins and ends quietly reaching maximum amplitude in the middle of its duration. Syllable repetition period varies from 470 to $500 \mathrm{~ms}$ at $22^{\circ} \mathrm{C}$. Each syllable includes 14-15 uniform pulses. Syllables from different parts of a song are similar in frequency spectra (Fig. 23).

REMARK. This species is known from Romania, Cyprus, several localities in Azerbaijan [Emelyanov, 2015], and from Lebanon [Picciau et al., 2016]. The locality in Kyrgyzstan is situated far eastwards from the known range; drawings of genitalia of recorded specimen are presented on Figs 31-33.

\section{Cixius towadensis Matsumura, 1914}

\section{Figs 26-28.}

MATERIAL. Russian Maritime Territory, Khasan District, ca. $15 \mathrm{~km}$ Southwest of Slavyanka, environs of Ryazanovka Village, 17.VII.2012. Calling signals of $1 \sigma^{7}$ recorded on disk at $22^{\circ} \mathrm{C}$.

SIGNALS. Calling signal consists of regularly repeated phrases including 4-6 uniform syllables of equal amplitude (Figs 26-27). Pauses between phrases range from 3 to $4 \mathrm{~s}$. Syllable repetition period averages $600-700 \mathrm{~ms}$ in our recordings. Each syllable consists of two pulses (Fig. 28). Male can sing unceasingly for several minutes.

Tribe Semonini

\section{Kuvera amurensis Anufriev, 1987}

Figs 36-40.

MATERIAL. Russian Maritime Territory, Khasan District, "Kedrovaya Pad" “ ("Cedar Valley”) Nature Reserve, environs of Primorskiy Village, 9.VIII.2010, calling signals of $2 \sigma^{\top} \sigma^{7}$ recorded on disk at $24-25^{\circ} \mathrm{C}$

SIGNALS. Calling signal is a succession of syllables (perhaps it should be referred to as a phrase) consisting of one low-amplitude and one high-amplitude pulse each. Duration of a signal averages 40-50 s (Figs 36-37). Syllable repetition period is unusually long and averages $1.3 \mathrm{~s}$ in our recordings (Figs 38-40). Male can sing unceasingly for several minutes producing phrases at intervals of 10-15 s.

\section{Kuvera vilbastei Anufriev, 1987 Figs 41-44.}

MATERIAL. Russian Maritime Territory, ca. $15 \mathrm{~km}$ Southwest of Slavyanka, environs of Ryazanovka Village, 17, 19.VII.2012, calling signals of $2 \sigma^{7} \sigma^{7}$ recorded on disk at 20 and $24^{\circ} \mathrm{C}$.

SIGNALS. Calling signal is similar to this of $K$. amurensis, but syllable repetition period averages $5.3 \mathrm{~s}$ and 

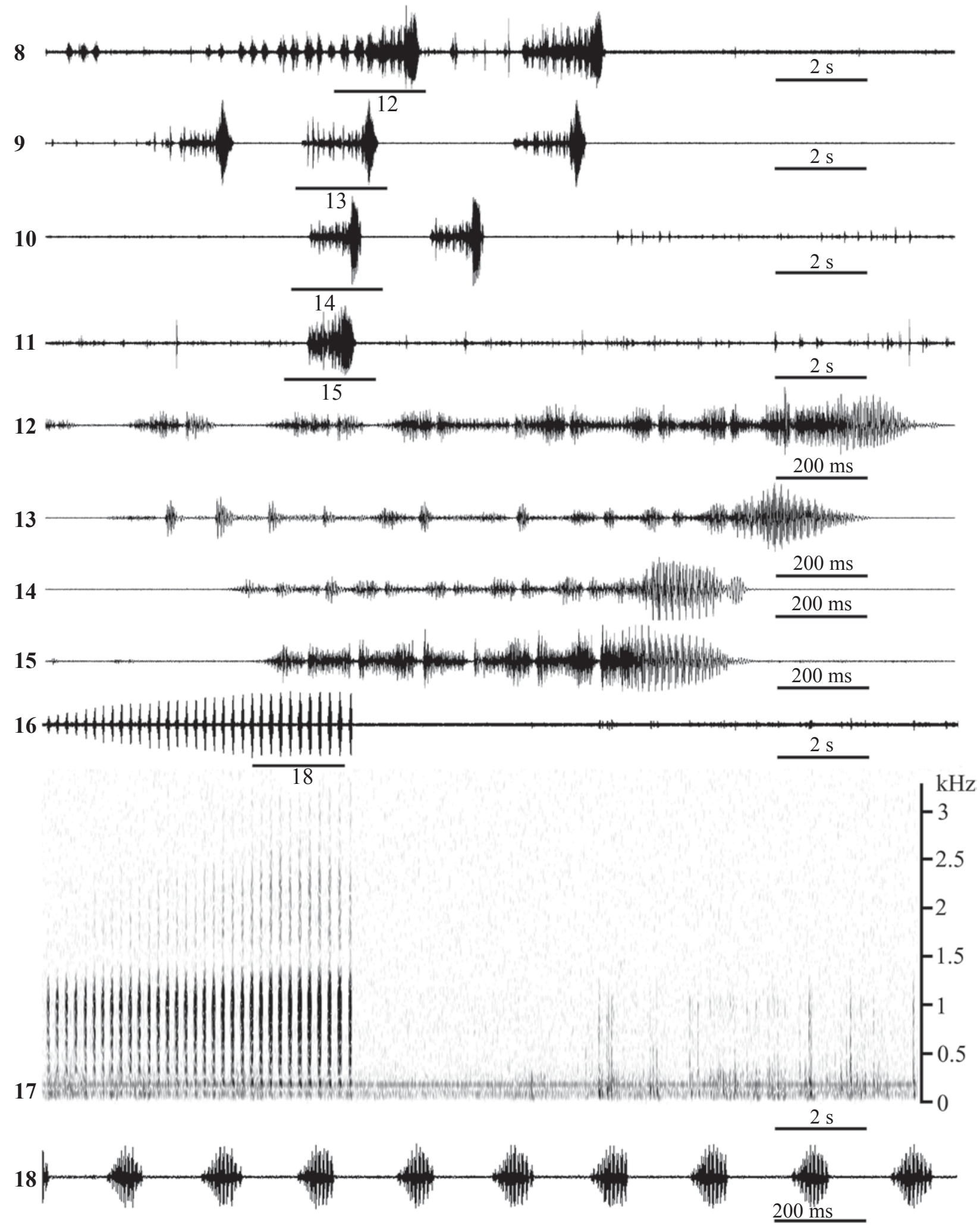

Figs 8-18. Calling signals of Unkanodes latespinosa (8-15) and Duilius fasciatus (16-18): 8-15 and 18 - oscillograms; 16-17 oscillogram and sonogram of the same signal. Faster oscillograms of the parts of signals indicated as " $12-15$ " and " 18 " are given under the same numbers.

Рис. 8-18. Призывные сигналы Unkanodes latespinosa (8-15) и Duilius fasciatus (16-18): 8-15 и 18 - осциллограммы; 16-17осциллограмма и сонограмма одного и того же сигнала. Фрагменты сигналов, обозначенные цифрами “12-15" и “18", представлены на осциллограммах под такими же номерами. 
duration of the song sometimes exceeds 2 minutes (Figs 41-44). Initial and final syllables in the signal have lower amplitude than the middle ones (Fig. 41).
10. Kuvera flaviceps (Matsumura, 1900)

Figs 45-48.

MATERIAL. Russian Maritime Territory, ca. $35 \mathrm{~km}$ Northeast of Chuguevka, environs of Zametnoe Village, 10.VII.2006. Calling signals of $1 \mathrm{O}^{7}$ recorded on disk at $21-22^{\circ} \mathrm{C}$.
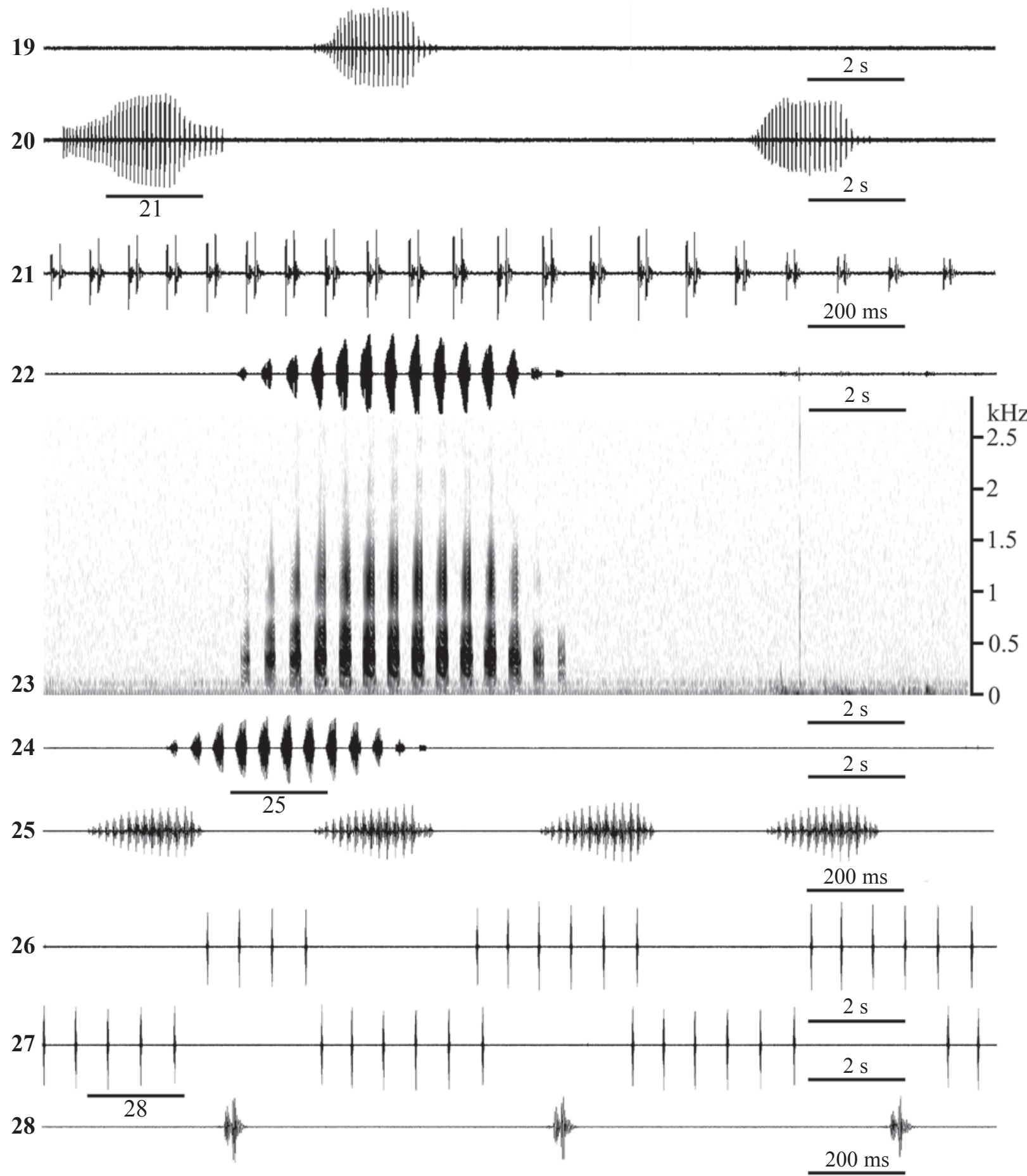

Figs 19-28. Calling signals of species of Cixius. 19-21 - C. sibiricus, 22-25 - C. granulatus, 26-28 - C. towadensis; 19-21 and 24-28 - oscillograms, 22-23 - oscillogram and sonogram of the same signal. Faster oscillograms of the parts of signals indicated as " 21 ", " 25 ", and " 28 " are given under the same numbers.

Рис. 19-28. Призывные сигналы видов рода Cixius. 19-21 - C. sibiricus, 22-25 - C. granulatus, 26-28 - C. towadensis; 19-21 и 24-28 - осциллограммы, 22-23 - осциллограмма и сонограмма одного и того же сигнала. Фрагменты сигналов, обозначенные цифрами “21”, “25” и “28”, представлены на осциллограммах под такими же номерами. 
SIGNALS. Calling signal is a phrase lasting for $12-15 \mathrm{~s}$. It consists of uniform pulses; pulse repetition period ranges from 59 to $69 \mathrm{~ms}$ at $21-22^{\circ} \mathrm{C}$ (Figs $45-48$ ). In our recordings, there is an abrupt drop of amplitude in the middle of each phrase (Figs 45-47); this phenomenon is usually observed in young males [Hoch, Howarth, 1993].

\section{Kuvera basarukini Emeljanov, 1998} Figs 49-51.

MATERIAL. Southern Sakhalin, environs of Sokol Town, from willows, 23.VII. 2015. Calling signals of $1 \mathrm{O}^{7}$ recorded on disk at $25^{\circ} \mathrm{C}$.
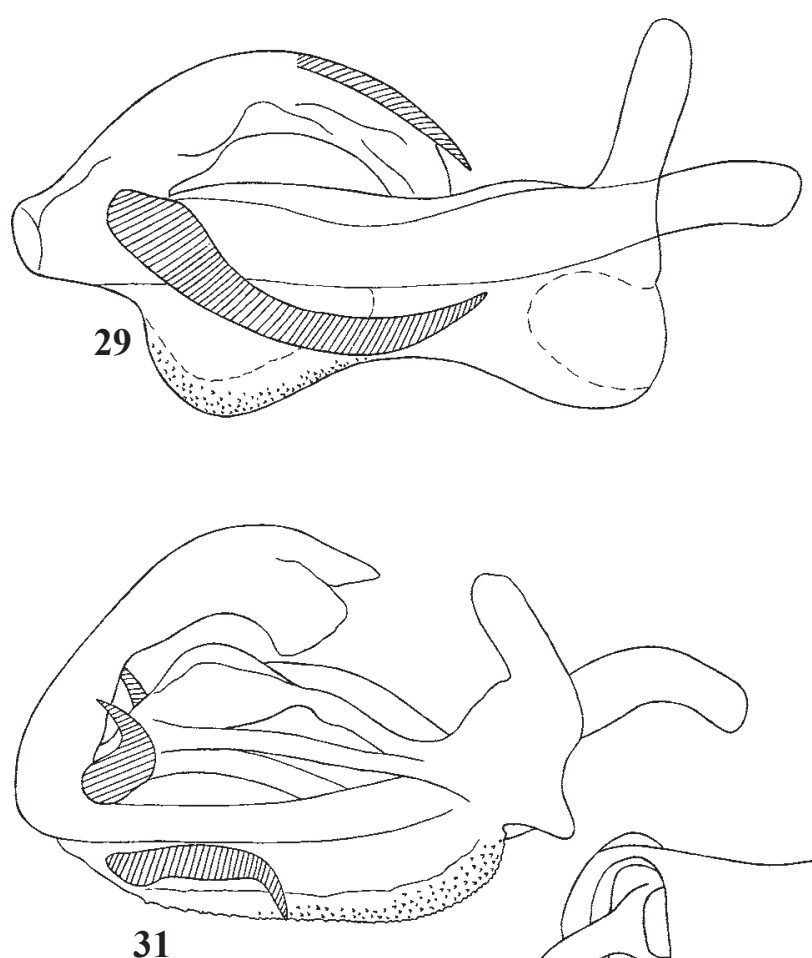

31
SIGNALS. Calling signal is very similar to this of $K$. flaviceps. It is a phrase lasting for $13-14 \mathrm{~s}$; in our recordings, initial ca. $0.5 \mathrm{~s}$ of each signal is missed (Figs 49-50). Pulse repetition period ranges from 75 to $81 \mathrm{~ms}$ at $25^{\circ} \mathrm{C}$ (Fig. 51).

REMARK. $K$. flaviceps occurs in the mainland of the Russian Maritime Territory and on Southern Kurile Islands whereas K. basarukini was found only on Sakhalin. These two species demonstrate an example of the signal similarity in allopatric species.

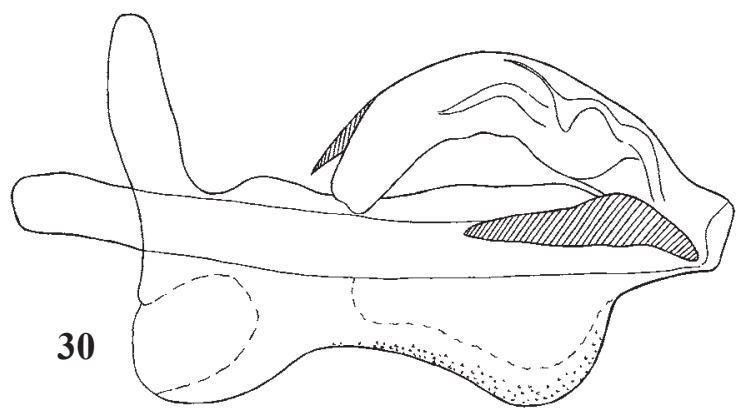

33
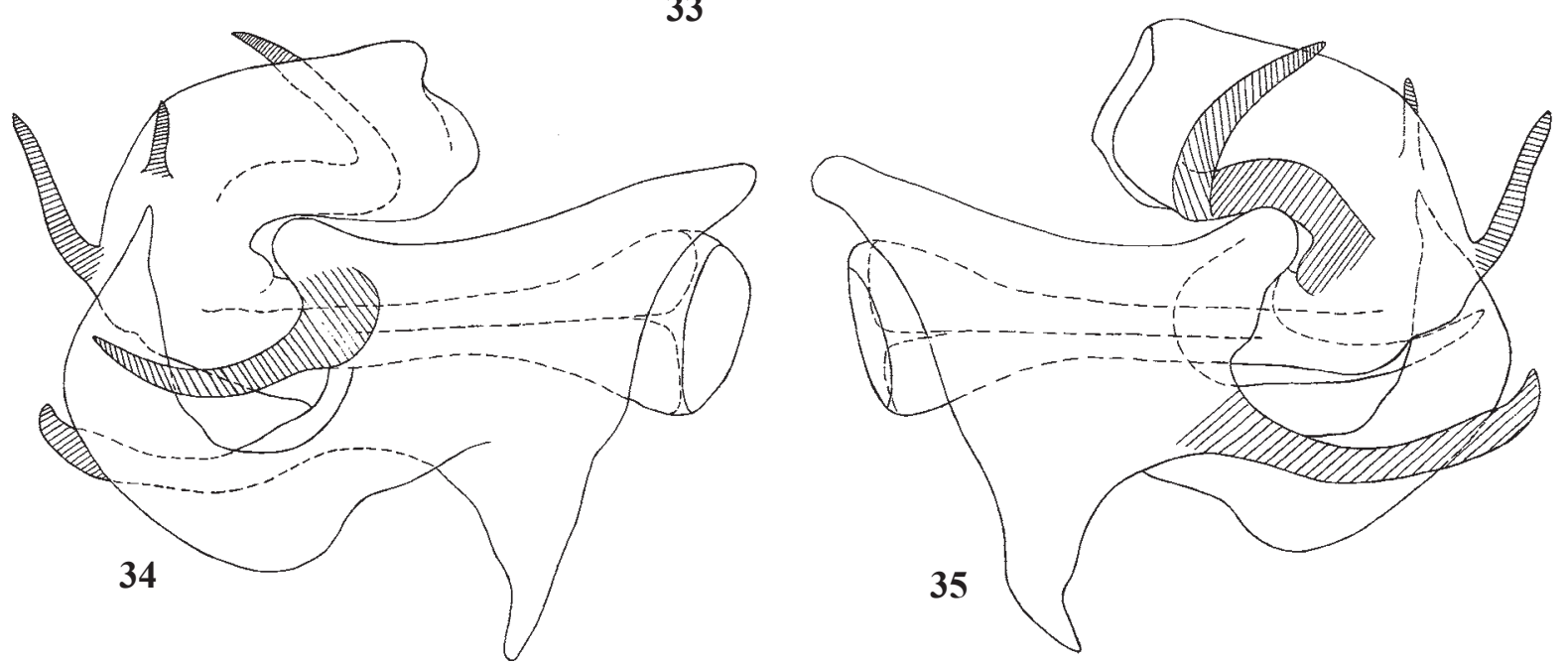

Figs 29-35. Male genitalia of Cixiidae: 29-30 - Cixius sibiricus; 31-33-C. granulatus; 34-35 - Reptalus narynensis; 29, $31-$ penis, right lateral view; 30,32 - same, left lateral view; 33 - anal tube, dorsal view; 34 - penis, dorsal view; 35 - same, ventral view.

Рис. 29-35. Гениталии самцов Cixiidae: 29-30 - Cixius sibiricus; 31-33-C. granulatus; 34-35 - Reptalus narynensis; 29 , 31 - пенис, вид справа; 30, 32 - то же, вид слева; 33 - анальная трубка сверху; 34 - пенис, сверху; 35 - то же, снизу. 


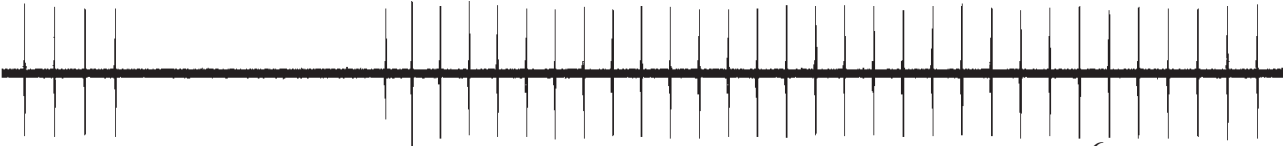
$6 \mathrm{~s}$

37

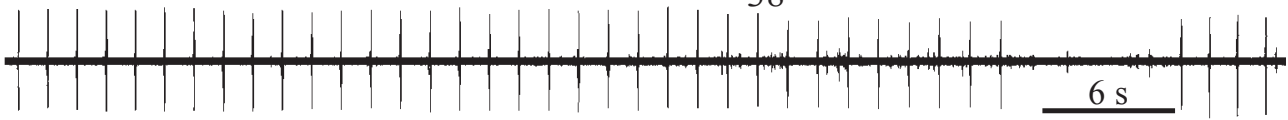

38

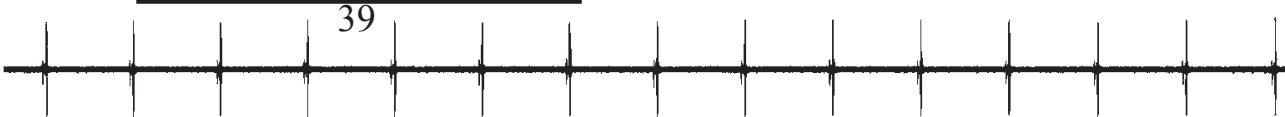

39

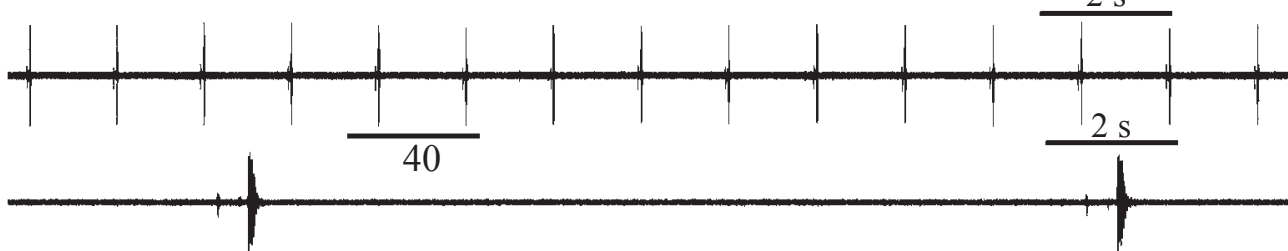

40

$200 \mathrm{~ms}$

41
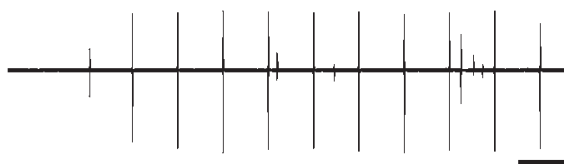

42

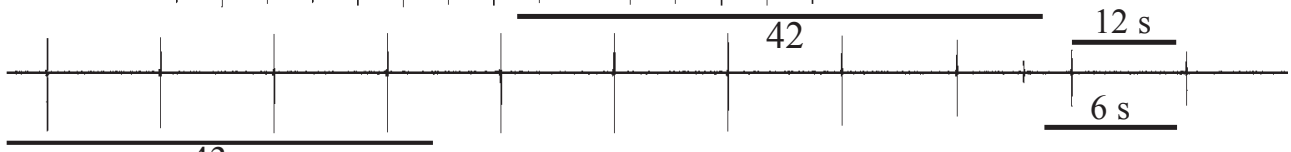

43

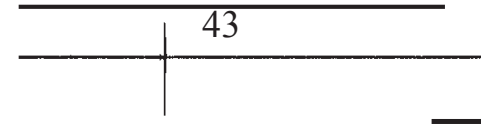

44

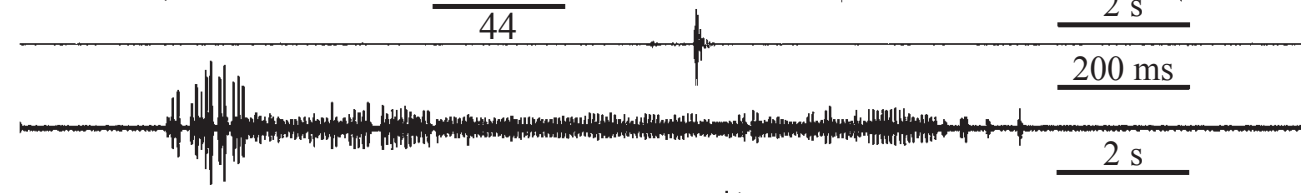

46

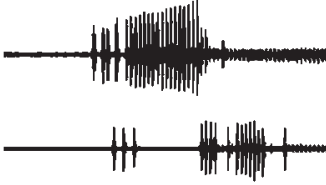

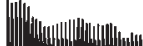

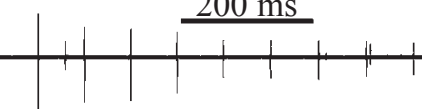

47

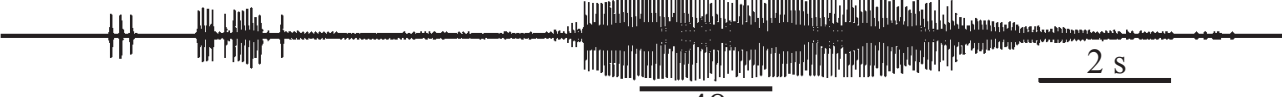

48

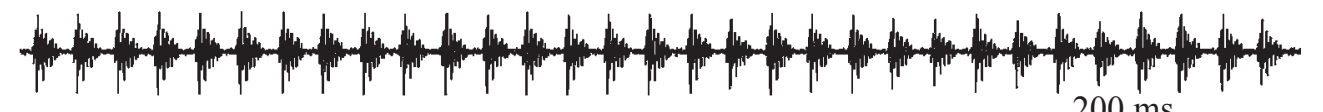

49

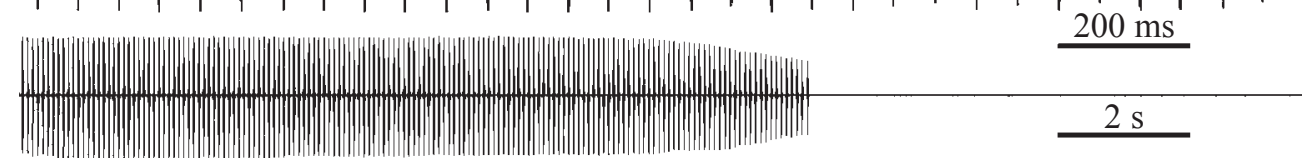

50
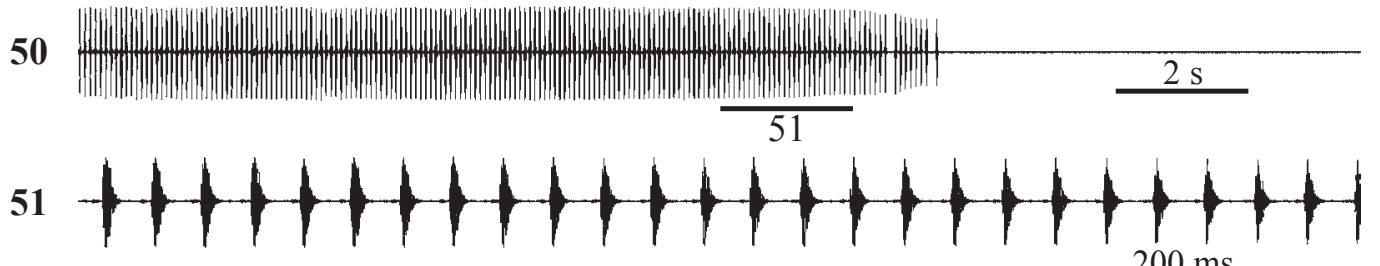

$200 \mathrm{~ms}$

Figs 36-51. Calling signal oscillograms of species of Kuvera: 36-40 - K. amurensis; 41-44 - K. vilbastei; 45-48 - K. flaviceps; 4951 - K. basarukini. Faster oscillograms of the parts of signals indicated as "38-40", " $42-44$ ", "48", and " 51 " are given under the same numbers.

Рис. 36-51. Осциллограммы призывных сигналов видов рода Kuvera: 36-40 - K. amurensis; 41-44 - K. vilbastei; 45-48 - K. flaviceps; 49-51 - K. basarukini. Фрагменты сигналов, обозначенные цифрами “38-40”, “42-44”, “48” и “51”, представлены на осциллограммах под такими же номерами. 


\section{Tribe Pentastirini}

\section{Hyalesthes mlokosiewiczi Signoret, 1879 Figs 52-55.}

MATERIAL. Kyrgyzstan, Ferghana Mtn. Range, Arslanbob Town, the bank of Kara-Kulak River, 14. VII. 2011. Calling signals of $4 \mathrm{O}^{\top} \mathrm{O}^{7}$ recorded on disk at $24^{\circ} \mathrm{C}$.

SIGNALS. Calling signal is a succession of 5-7 pulses, the $2^{\text {nd }}$ and the $3^{\text {rd }}$ pulses usually reaches maximum amplitude; formally, it could be referred to as a syllable (Figs 52-55). Syllables follow each other with regular intervals, but it is impossible to determine their duration in our recordings, because two or three males were singing alternately (Figs 52-53).

\section{Hyalesthes obsoletus Signoret, 1865 Figs 56-57.}

MATERIAL. Extreme Southeast of Saratov Area, 2-3 km East of Ozinki Town, Artemisia abrotanum L. in the steppe near the pool, 30.VI.2004. Calling signals of $3 \sigma^{\top} \sigma^{\top}$ recorded on tape at $27^{\circ} \mathrm{C}$.

REFERENCES TO SIGNALS. Tishechkin [2003], males from Azerbaijan; Mazzoni et al. [2010], males from Italy.

SIGNALS. Calling signal is a phrase lasting for 2-3 s and consisting of one long and several shorter syllables (Fig. 56), the first or the second syllable being the longest (Fig. 57).

COMPARATIVE NOTES. In temporal pattern, signals of individuals from Saratov Area are similar to these described earlier.

\section{Pentastiridius laevifrons (Mitjaev, 1975) Figs 58-59.}

MATERIAL. Astrakhan' Area, Western Shore of Baskunchak Lake, near Bol'shoy Bogdo Mtn., Anabasis aphylla L., 1.VII.2005. Calling signals of $1 \mathrm{O}^{7}$ recorded on disk at $29-30^{\circ} \mathrm{C}$.

SIGNALS. Calling signal is a phrase lasting for about 2.5-3 s. It begins abruptly, slightly decreases and then considerably increases in amplitude (Fig. 58). Pulse repetition period decreases from about $40 \mathrm{~ms}$ at the beginning of a phrase to 30-27 ms at its end (Fig. 59).

\section{Reptalus narynensis Emeljanov et Tishechkin, 2012}

Figs 34-35, 60-63.

MATERIAL. Kyrgyzstan, Inner Tien Shan Mts., Kekemeren River Gorge ca. $10 \mathrm{~km}$ upstream from Aral Town, 29.VI.2013. Calling signals of $1 \mathrm{O}^{7}$ recorded on disk at $21^{\circ} \mathrm{C}$.

REFERENCES TO SIGNALS. Oscillograms of calling signals of one paratype from the lowlands of West Tien Shan Mts. are given in Emelyanov and Tishechkin [2012].

SIGNALS. Calling signal is a phrase lasting for about $5 \mathrm{~s}$ (Figs 60-63). It consists of syllables including 9-13 pulses each and following each other with a period of about 130 $160 \mathrm{~ms}$. In the $2^{\text {nd }}$ half or the last third of a phrase the gaps between syllables become indistinct and the signal temporal pattern becomes irregular.

COMPARATIVE NOTES. Signal pattern in males from different localities is similar.

REMARK. $R$. narynensis was described from two localities in hot arid regions of West Tien Shan Mts. The finding of this species in the Inner Tien Shan Mts. i.e. in the region with a much more harsh climate indicates that it can have wider range than might have been expected. Drawings of penis of a recorded specimen are presented on Figs 34-35.

\section{Reptalus flavinervis (Kusznezov, 1937) Figs 64-71.}

MATERIAL. 1. South Kazakhstan, Syrdaryinsky Karatau Mtn. Range, near Biylikol' Lake, Sayasay Gorge, Artemisia subg. Seriphid- ium in mountain steppe, 13.VI.2016, calling signals of $1 \sigma^{7}$ recorded on disk at $34^{\circ} \mathrm{C}$. 2. Kyrgyzstan, Turkestan Mtn. Range, environs of Katran Village, Layli-Mazar River 2-3 km upstream from the source of Lyaylyak River, Artemisia subg. Seriphidium in mountain steppe, 24.VI.2016, calling signals of $2 \sigma^{7} \sigma^{7}$ recorded on disk at $26^{\circ} \mathrm{C}$.

SIGNALS. Calling signal is a phrase consisting of several short syllables and one long syllable. The number of short syllables usually varies from 2 to 4-5 (Figs 64-67 and 6971), but occasionally reaches 10-20 and more (Fig. 68).

COMPARATIVE NOTES. Signals of individuals from two localities are almost identical (Figs 64-65 and 66-71).

\section{Family Meenoplidae \\ 17. Eponisiella paludicola (Vilbaste, 1968)}

Figs 72-79.

MATERIAL. Russian Maritime Territory: (1) ca. 35 km Northeast of Chuguevka, environs of Zametnoe Village, Carex sp. in the bog, 10.VII.2006, ca. $20 \sigma^{7} \sigma^{7}$ were present on the plant attached to vibration sensor (gramophone cartridge), several calling signals recorded on disk at $30^{\circ} \mathrm{C}$, the number of singing males is unknown; (2) "Kedrovaya Pad" " ("Cedar Valley") Nature Reserve, environs of Primorskiy Village, Carex sp. on wet meadow, 17.VIII.2010, calling signals of 5-6 $\sigma^{7} \sigma^{7}$ recorded on disk at $26-27^{\circ} \mathrm{C}$.

SIGNALS. The only signal that was recorded in this species is a long phrase, lasting from $7-8 \mathrm{~s}$ to 1 minute and more (Figs 72-77). The phrase consists of syllables usually including 2-3 pulses each (Figs 78-79). The shape of syllables is more or less constant, but the change of their amplitude follows a pattern. As a rule phrase begins with an abrupt increase of amplitude followed by more gradual decrease; usually it includes 2-3 such amplitude maxima. The phrase ends with a train of rather low-amplitude syllables; it can last for 15-20 s or, on the contrary, is almost reduced. Phrases follow each other with gaps having duration from 200-300 ms to several seconds.

COMPARATIVE NOTES. Signals of individuals from two localities are almost identical (Figs 72-75, 78 and 76-77, 79).

Family Dictyopharidae

Subfamily Dictyopharinae

\section{Dictyophara nekkana Matsumura, 1940} Figs 80-84.

MATERIAL. East Siberia, South Buryatia, 4-5 km North of Selenduma Town, steppes in the valley of Temnik River, 12.VII.2007. Calling signals of $2 \mathrm{O}^{7} \mathrm{O}^{7}$ recorded on disk at $26-29^{\circ} \mathrm{C}$.

SIGNALS. Calling signal pattern is typical to Dictyophara [Tishechkin, 2003]; it is a phrase lasting for 5-6 s (Figs 80-81). The phrase consists of uniform pulses (Figs 83-84). The main part of a phrase has constant amplitude, only in the last one-fifth of a signal it drops abruptly. The frequency spectrum remains more or less constant throughout a phrase (Fig. 82).

\section{Subfamily Orgeriinae \\ 19. Elysiaca ferganensis (Oshanin, 1913)} Figs 85-88.

MATERIAL. Kyrgyzstan, Chatkal Mtn. Range, Sary-Chelekskiy Biosphere Nature Reserve, environs of Arkyt Village, mesophyte meadows, 23. VII. 2008. Calling signals of $2 \sigma^{7} \sigma^{7}$ recorded on disk at $23-24^{\circ} \mathrm{C}$

SIGNALS. Calling signal is a phrase lasting for 15-20 s and consisting of uniform short pulses (Figs 85-88). At the beginning of a phrase pulse repetition period rapidly decreases and shortly becomes constant (about 40 ms, Figs 87-88). The phrase ends abruptly; one or several additional pulses separated by rather long gaps can be present at its end. 

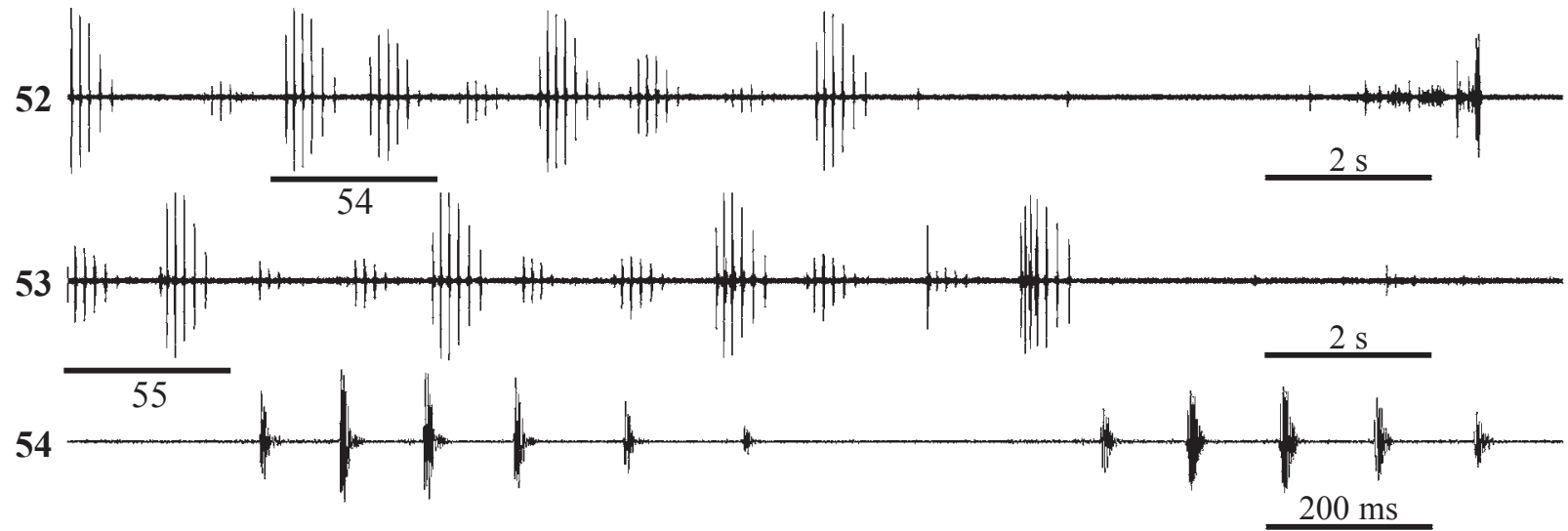

55
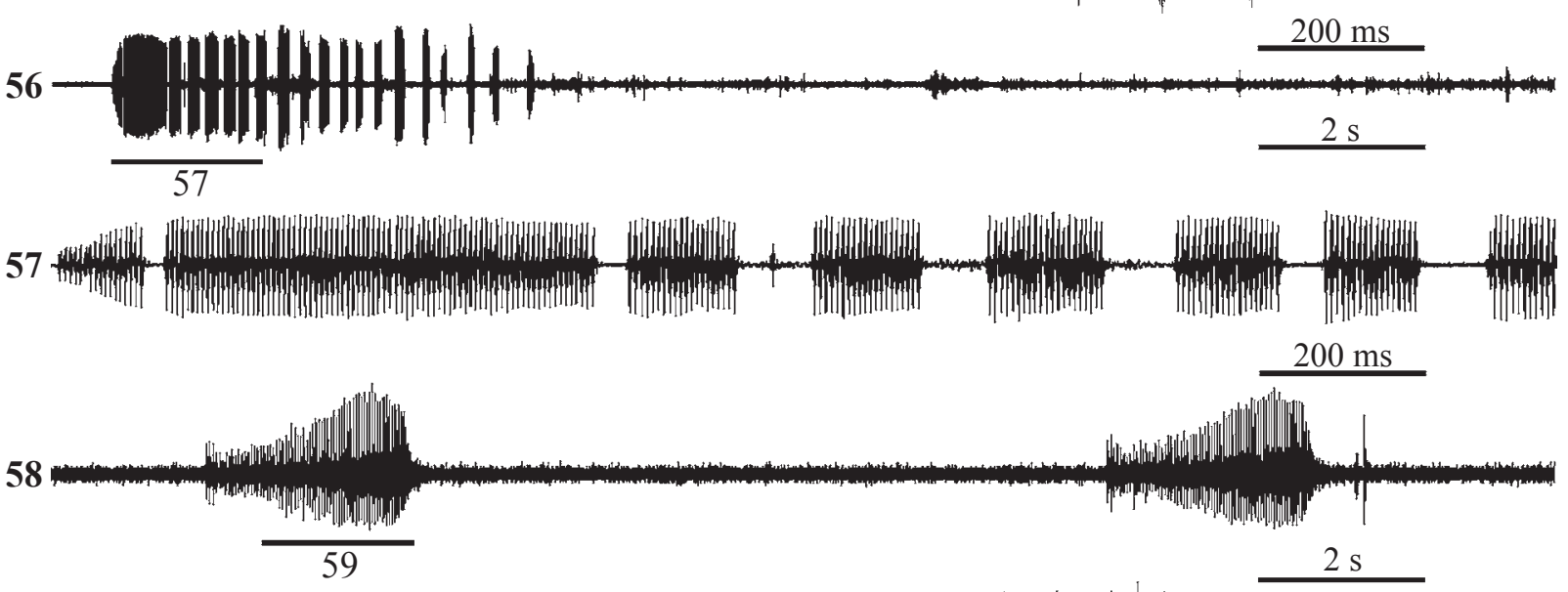

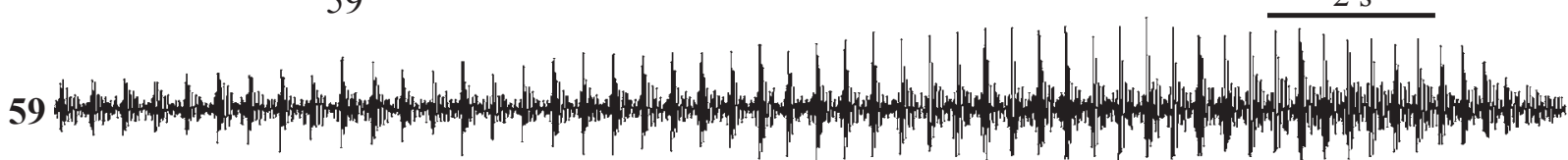

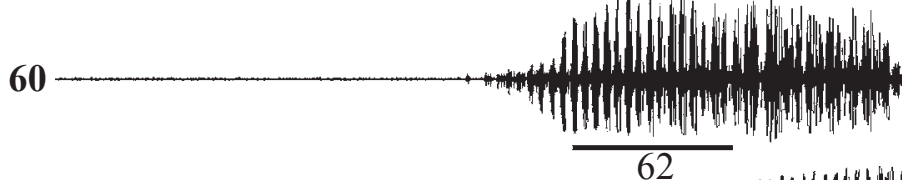

61

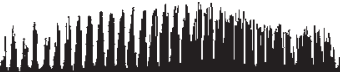

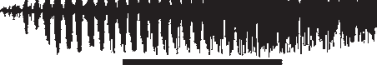

$2 \mathrm{~s}$

62 W $200 \mathrm{~ms}$

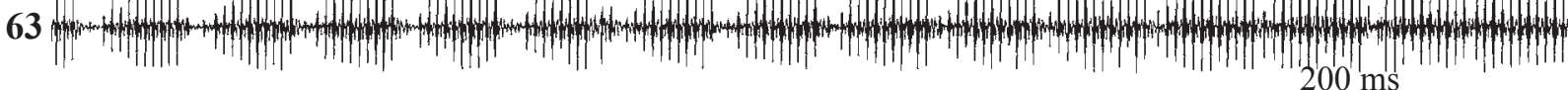
Pentastiridius laevifrons; 60-63 - Reptalus narynensis. Faster oscillograms of the parts of signals indicated as "54-55", "57", "59", and "62-63" are given under the same numbers.

Рис. 52-63. Осциллограммы призывных сигналов Cixiidae: 52-55 - Hyalesthes mlokosiewiczi; 56-57 - H. obsoletus; 58-59Pentastiridius laevifrons; 60-63 - Reptalus narynensis. Фрагменты сигналов, обозначенные цифрами "54-55”, “57”, "59” и "62-63”, представлены на осциллограммах под такими же номерами. 
64

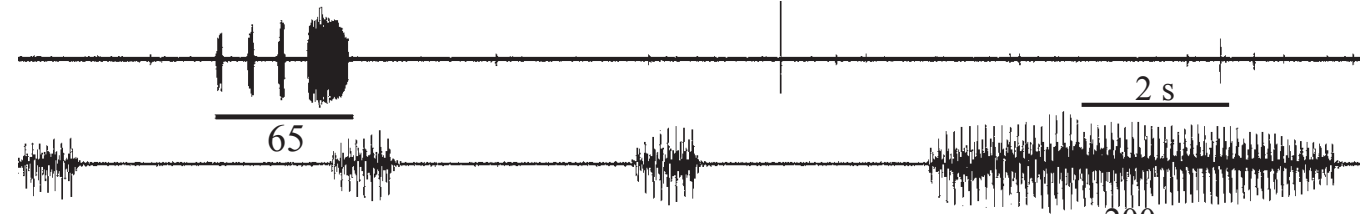

66

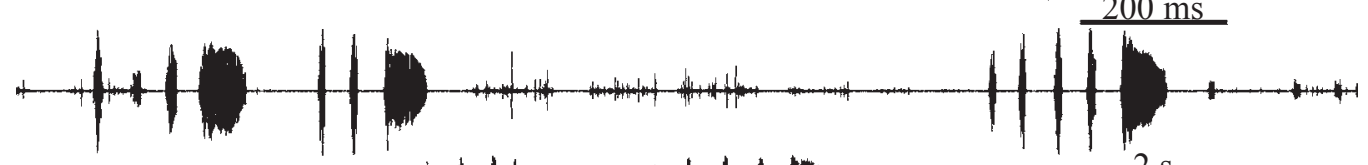

67

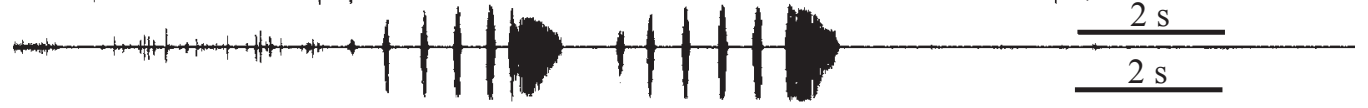

68

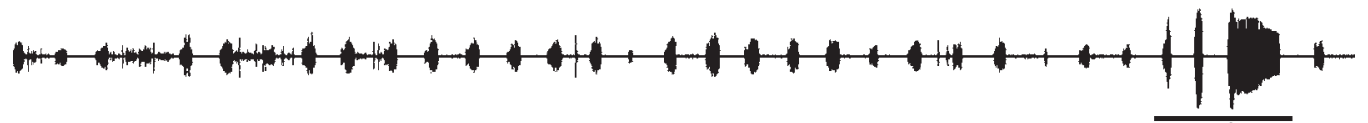

69

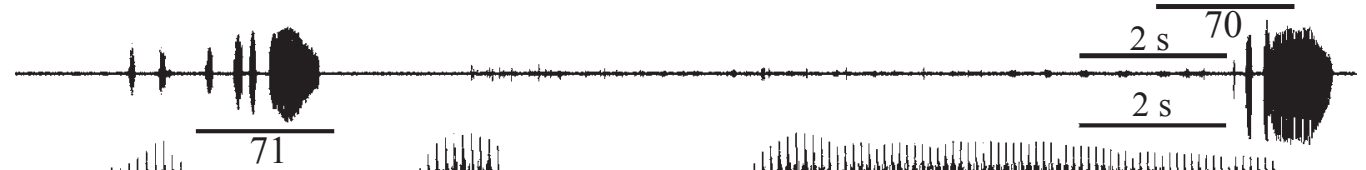

70

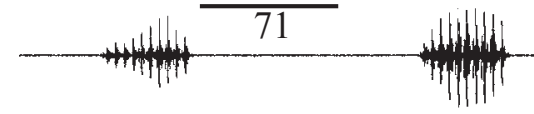

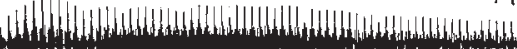

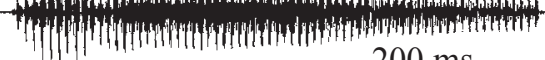

$$
200 \mathrm{~ms}
$$

71

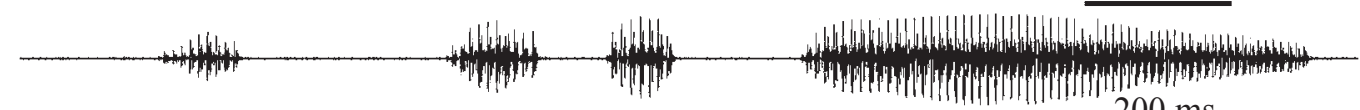

72

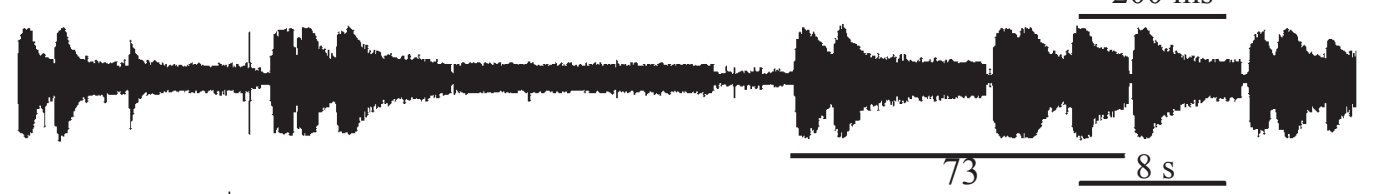

73

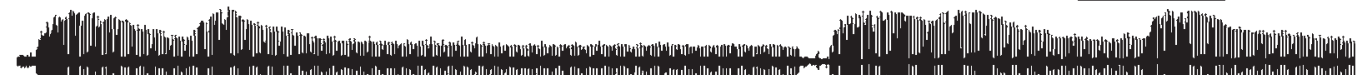
-

74

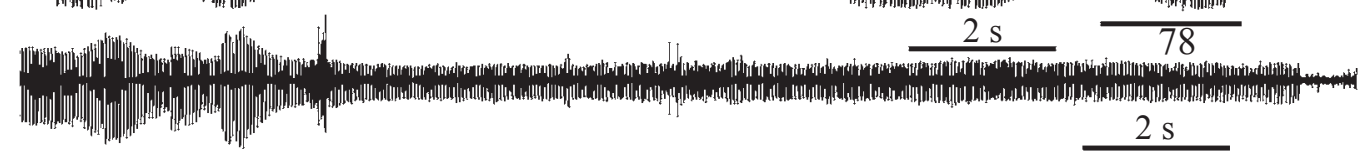

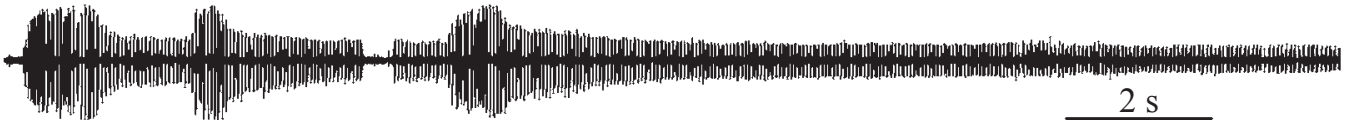
-

Figs 64-79. Calling signal oscillograms of Reptalus flavinervis (64-71) and Eponisiella paludicola (72-79): 64-65 — male from Kazakhstan (Karatau Mtn. Range); 66-71 - males from Kyrgyzstan (Turkestan Mtn. Range); 72-75 and 78 - males from "Kedrovaya Pad" "Nature Reserve; 76-77 and 79 - males from Chuguevka. Faster oscillograms of the parts of signals indicated as "65", "70-71", "73", and "78-79" are given under the same numbers.

Рис. 64-79. Осциллограммы призывных сигналов Reptalus flavinervis (64-71) и Eponisiella paludicola (72-79): 64-65 — самец из Казахстана (Каратау); 66-71 - самцы из Кыргызстана (Туркестанский хр.); 72-75 и 78 - самцы из заповедника «Кедровая Падь»; 7677 и 79 - самцы из Чугуевки. Фрагменты сигналов, обозначенные цифрами “65”, “70-71”, “73” и “78-79”, представлены на осциллограммах под такими же номерами. 


\section{Family Caliscelidae \\ 20. Peltonotellus turgidus Emeljanov, 2008 Figs 89-93.}

MATERIAL. South Kazakhstan, foothills of Zailiyskiy Alatau Mountain Ridge in the environs of Almaty. 4.VII.1994. Calling signals of $1 \mathrm{O}^{7}$ recorded on tape at $30^{\circ} \mathrm{C}$. Also, in this locality paratypes of this species were collected [Emelyanov, 2008].

REFERENCES TO SIGNALS. Tishechkin [1998], same male as in the present paper, as Peltonotellus sp.; Tishechkin [2003], same male as in the present paper, as Aphelonema sp.

SIGNALS. Calling signal is a complex phrase lasting for 10-20 s (Figs 89-93). Different components of a phrase differ from each other in frequency spectra (Fig. 90).

REMARK. Signal recordings were made in 1994; at that time Prof. A.F. Emelyanov was going to describe this species, but postponed this job for the future. For this reason, in our papers [Tishechkin, 1998, 2003] this species was mentioned as Peltonotellus sp. and Aphelonema sp., respectively. Here we give oscillograms of these recordings under the proper name to avoid misinterpretation.

\section{Acromega scurrilis (Stål, 1862) Figs 94-98.}

MATERIAL. East Siberia, South Buryatia, steppes in the valley of Selenga River ca. $5 \mathrm{~km}$ upstream from Novoselenginsk Village, 4.VII.2007. Calling signals of $3 \mathrm{O}^{7} \mathrm{O}^{7}$ recorded on disk at $26^{\circ} \mathrm{C}$.

SIGNALS. As in P. turgidus, calling signal is a complex phrase lasting for 5-18 s and consisting of several different parts (Figs 94-98). Phrases follow each other with irregular intervals.

\section{Discussion}

As can be seen from the oscillograms, calling signals of the representatives of most fulgoroid families have rather simple temporal pattern. The only exceptions are Delphacidae and Caliscelidae. In these families both temporal, and frequency patterns sometimes are more complex.

Interspecific differences in signal pattern for the most part are quite distinct. For instance, signals of three sympatric similar in morphological characters species of Kuvera (K. amurensis, K. vilbastei, and K. flaviceps) differ distinctly in temporal characteristics (Figs 3648). On the other hand, signals of allopatric species (K. flaviceps occurring on the mainland of the Russian Far East and on Kurile Islands and K. basarukini occurring on Sakhalin) do not differ in phrase duration and pulse repetition period.

In small Auchenorrhyncha, the pause between male calling and female reply as a rule is either very short (e.g. 20-30 ms in Apartus michalki; Kunz et al., 2014) or absent, because the end of calling overlaps with the beginning of the reply (e.g. in Aphrodes makarovi Zakhvatkin, 1948 (Homoptera: Cicadellidae); de Groot et al., 2012). This indicates that female can recognise the male calling almost immediately after hearing the whole signal of even its part. In this respect, signals with very long gaps between syllables represent rather difficult task for female. Signals of $K$. amurensis, $K$. vilbastei, and Cixius towadensis sound as separate clicks to the human ear. At first it is difficult to recognise any regular pattern in these sounds and to realise that this is a signal produced by insect but not a noises from its movements, electrical interference, etc. Apparently, the conspecific signal recognition in these species takes much more time than in most Auchenorrhyncha species, since female must at least hear several syllables to determine their repetition period. For example, in K. amurensis a part of signal containing five syllables has a duration of $5.2 \mathrm{~s}$, and in $K$. vilbastei it averages $21 \mathrm{~s}$. Investigation of duetting behaviour in such species would be of great interest.

All species studied move periodically from plant to plant and produce calling signals on each stem to determine the presence of a receptive female. This behaviour is known as a "call-fly" or "call-walk" strategy and was described in many other Auchenorrhyncha species. This feature can be used during signal recording. Under experimental conditions, if the caged male stopped jumping from one place to another and settled on the stem, there is a good chance that it will produce calling in a few seconds. And vice versa, if the male is sitting motionless for too long time it is advisable to make it jump from one stem to another.

The only form of male-male competitive behaviour observed in most Fulgoroidea families is calling signal alternation [Tishechkin, 2003; Virant-Doberlet, Žežlina, 2007]. Two known exceptions are Delphacidae and Caliscelidae. In both families male-male competitive behaviour quite often is accompanied by specialized signals differing from the calling of a single male [Ichikawa, 1982; Tishechkin, 2003]

In temperate zone Auchenorrhyncha traditionally are considered to be diurnal insects; accordingly, it had been expected, that they sing during the daytime. In the vast majority of species such, indeed, is the case. However, recently it was demonstrated that at least some species have another daily rhythm of activity. Thus, Apartus michalki (Wagner, 1948) (Homoptera: Cixiidae) showed mating only at dawn, between 19:00 and 22:00 [Kunz et al., 2014] and in Metcalfa pruinosa (Say, 1830) (Homoptera: Flatidae) most signals were recorded between 00:00 and 04:00 [Virant-Doberlet, Žežlina, 2007]. Similar situation we have observed in the Far-Eastern species, Ledra auditura Walker, 1858 (Homoptera: Cicadellidae: Ledrinae): in all cases males started singing only after dusk (ca. after 23.00). It should be added that this species is difficult to collect by sweep-net, but it often flies to the light sources and can be found almost under every street lamp in small towns and villages in the Russian Maritime Province.

Virant-Doberlet and Žežlina [2007] offered several hypotheses to explain nocturnal pattern of acoustic activity in M. pruinosa. One of the reasons might be the time segregation of acoustic communication cannels between sympatric species producing similar signals. Indeed, in many fulgoroids calling signal pattern is similar. For this reason, their coexistence in the same plant community is possible only due to time sharing of acoustic environment. Partitioning of singing time between the members of tropical dusk chorus is a usual 

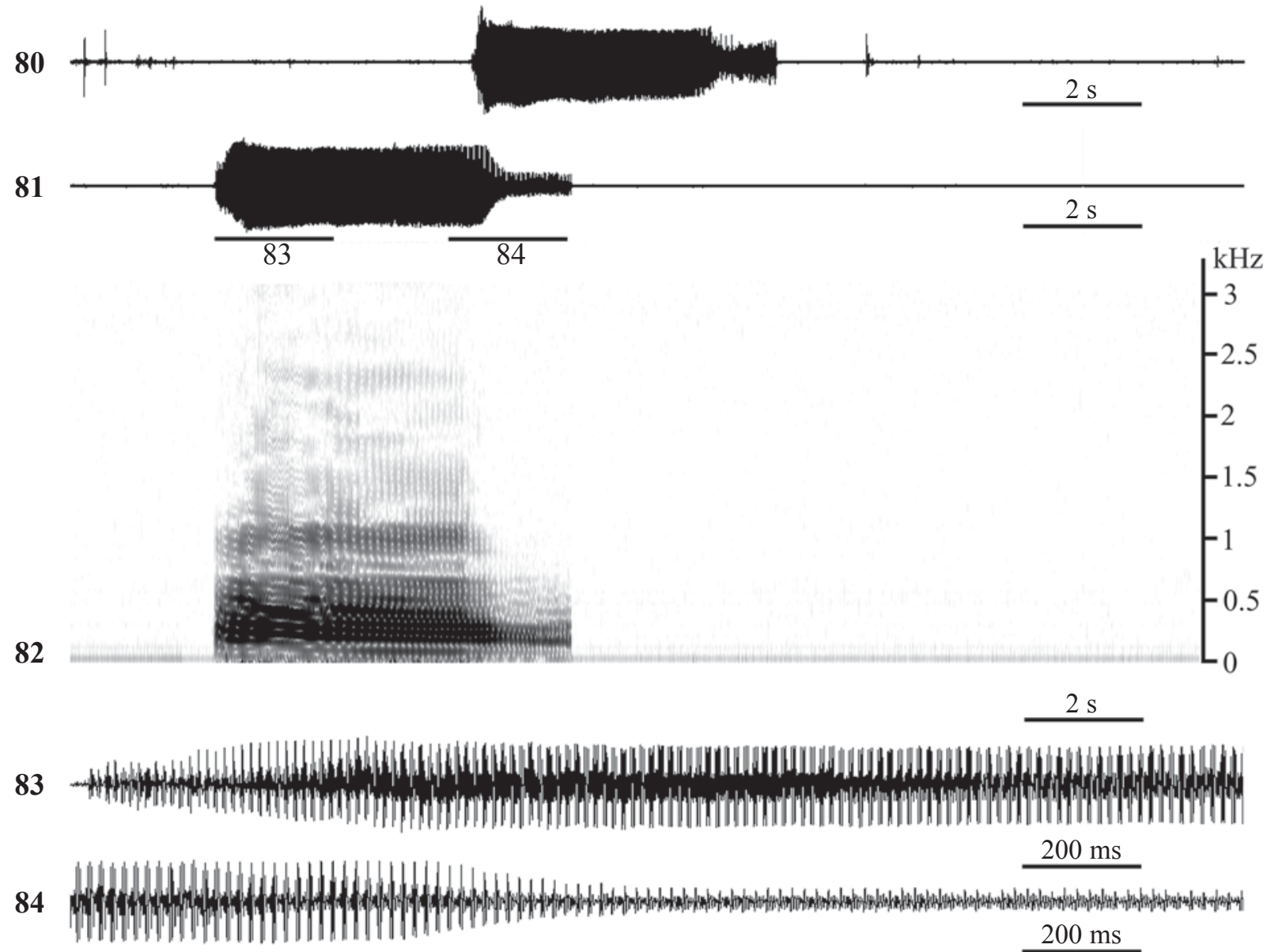

85

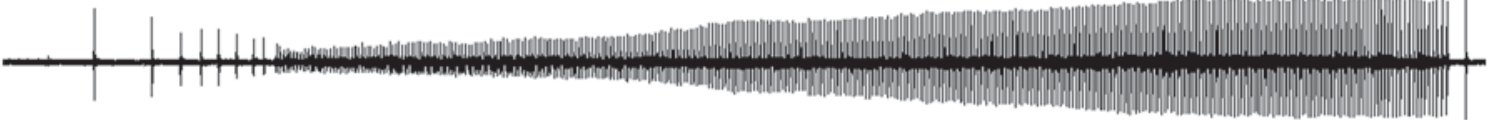

86

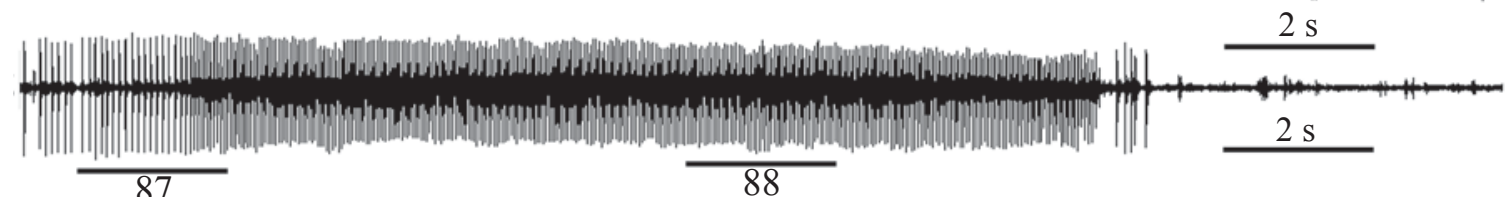

87

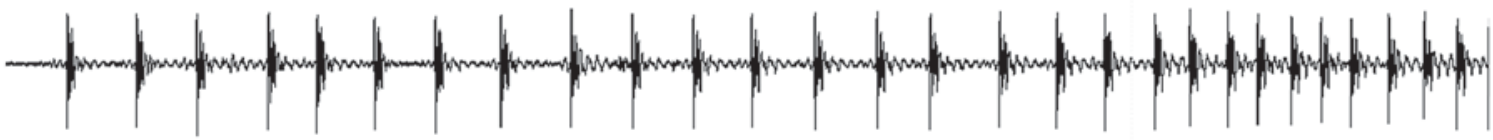

$200 \mathrm{~ms}$

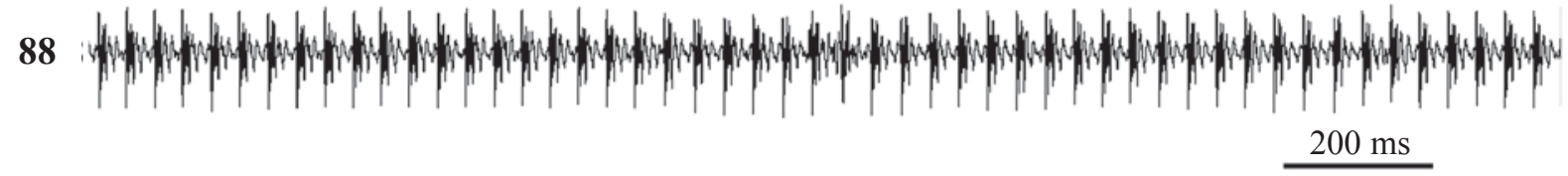

Figs 80-88. Calling signals of Dictyopharidae: 80-84 - Dictyophara nekkana; 85-88 - Elysiaca ferganensis; 80 and 83-88 oscillograms, 81-82 - oscillogram and sonogram of the same signal. Faster oscillograms of the parts of signals indicated as " $83-84$ " and "87-88" are given under the same numbers.

Рис. 80-88. Призывные сигналы Dictyopharidae: 80-84 - Dictyophara nekkana; 85-88 - Elysiaca ferganensis; 80 и 83-88 осциллограммы, 81-82 - осциллограмма и сонограмма одного и того же сигнала. Фрагменты сигналов, обозначенные цифрами “83-84” и “87-88”, представлены на осциллограммах под такими же номерами. 
89
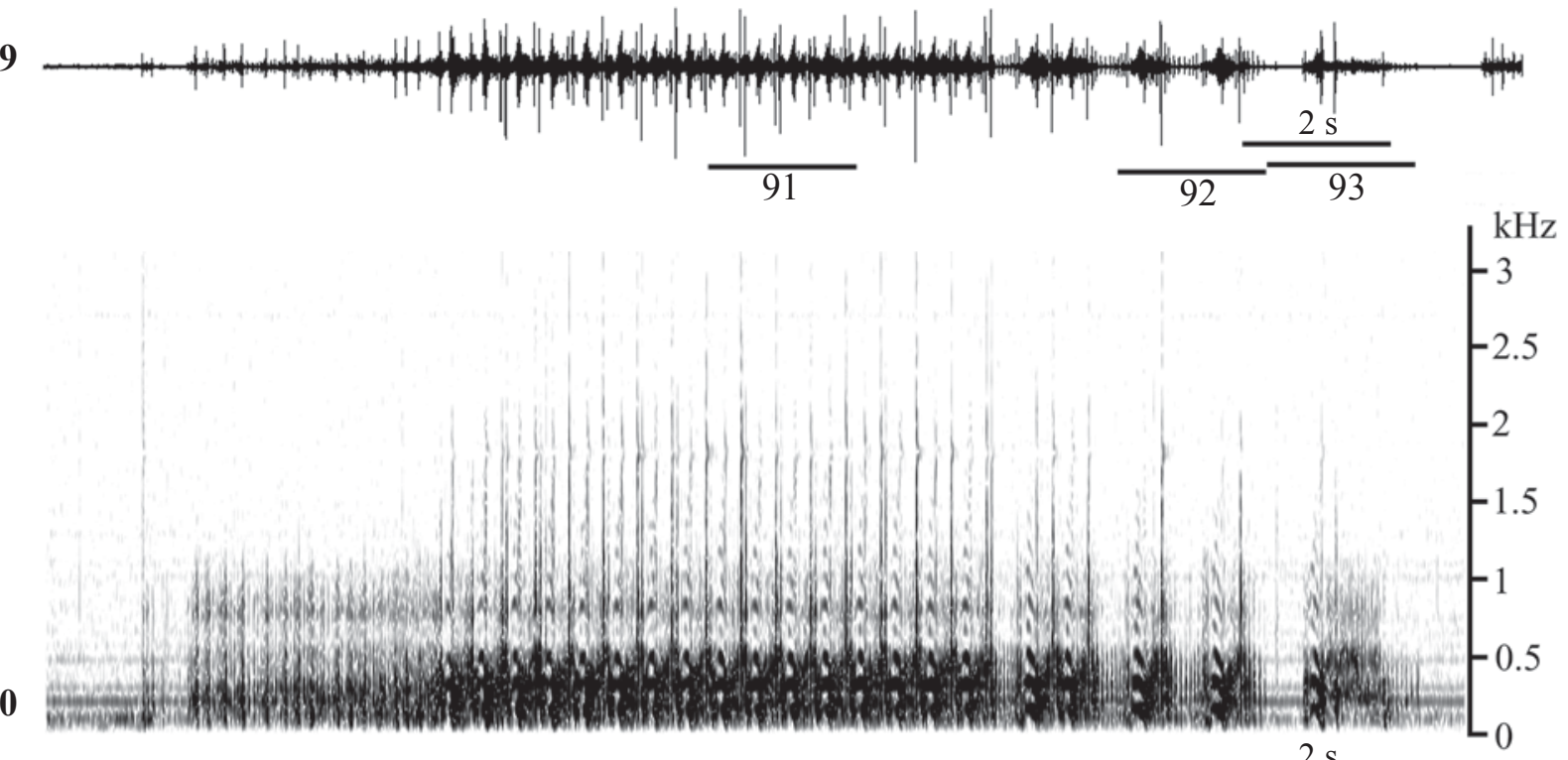

\section{0}

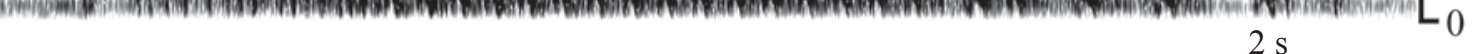
91 m.t.

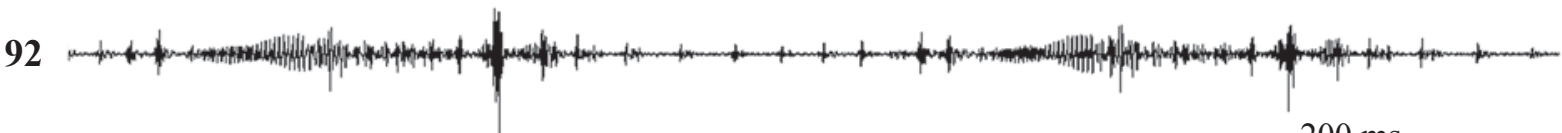
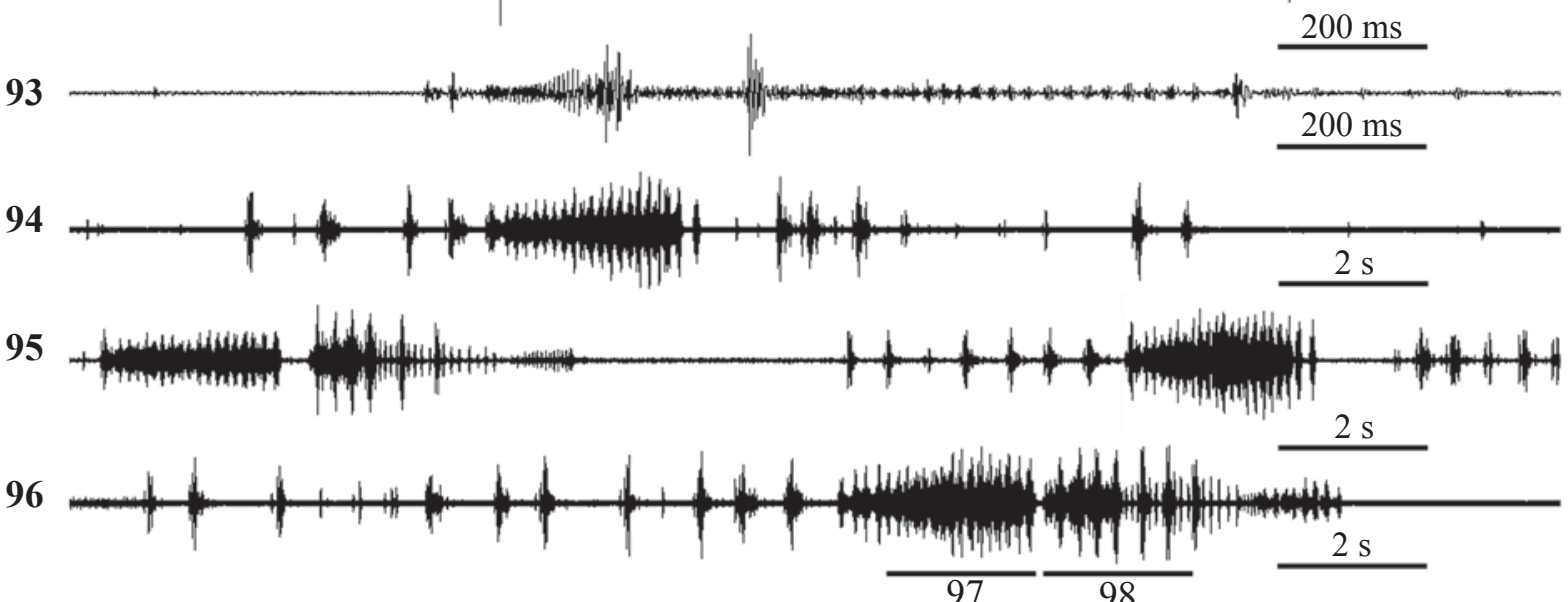

97
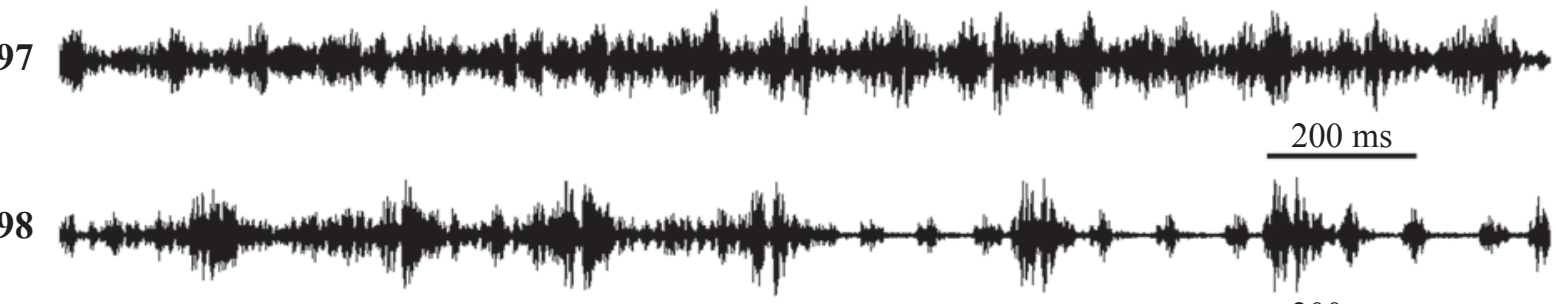

$$
200 \mathrm{~ms}
$$

Figs 89-98. Calling signals of Caliscelidae: 89-93 - Peltonotellus turgidus; 94-98 - Acromega scurrilis; 89-90 - oscillogram and sonogram of the same signal, 91-98 — oscillograms. Faster oscillograms of the parts of signals indicated as "91-93" and "97-98" are given under the same numbers.

Рис. 89-98. Призывные сигналы Caliscelidae: 89-93-Peltonotellus turgidus; 94-98 - Acromega scurrilis; 89-90- осциллограмма и сонограмма одного и того же сигнала, 91-98 - осциллограммы. Фрагменты сигналов, обозначенные цифрами “91-93" и "97-98", представлены на осциллограммах под такими же номерами. 
phenomenon [Wolda, 1993; Riede, 1996]. Similar case in temperate zone was discovered in the communities of the grasshoppers of the tribe Bryodemini (Orthoptera: Acrididae: Oedipodinae) in South Siberia [Tishechkin, 2010]. Despite the facts that, first, most Acrididae in Palaearctic are diurnal insects and, second, in Siberia the temperature drops sharply after sunset, acoustic activity peak in one species is shifted to the twilight time.

Usually, the number of species of Cixiidae or/and Dictyopharidae in the same biotope or plant community is not great, not to mention the fact that most other Fulgoroidea families are represented in temperate zone only by few species. We have collected Cixius sibiricus in the same place and on the same host with Hyalesthes obsoletus in Saratov Area; Kuvera vilbastei and Cixius towadensis were found in the same locality, but in different plant communities; Reptalus flavinervis in Kazakhstan and Kyrgyzstan dwelled in mountain steppes together with one or two species of Orgeriinae which signals were not recorded. All other species discussed above lived alone; no other fulgoroids were found in the same biotopes. Under these conditions simple signal pattern does not prevent successful intraspecific communication. Investigation of more species-rich communities of Fulgoroidea in future would allow us to learn more about partitioning of communication channels in these insects.

ACKNOWLEDGEMENTS. I am greatly indebted to Nataliya Burlak (Sergiev Posad, Moscow Area) for the help and support during the fieldwork in Lower Volga Region, Central Asia, and the Russian Far East in 2010-2013.

The study was supported by the Russian State program No. AAAA-A16-116021660095-7 (preparation of illustrations and manuscript) and Russian Science Foundation, grant No. 14-50-00029 (fieldwork in 2015-2016 and data handling).

\section{References}

Bieman C.F.M. den. 1986. Acoustic differentiation and variation in planthoppers of the genus Ribautodelphax (Homoptera, Delphacidae) // Netherlands J. Zool. Vol.36. No.4. P.461-480.

Bieman C.F.M. den. 1987. Variability in female calling signals in mixed populations of pseudogamous forms and bisexual Ribautodelphax species (Homoptera: Delphacidae) // Netherlands J. Zool. Vol.37. No.1. P.43-58.

Booij C.J.H. 1982. Biosystematics of the Muellerianella complex (Homoptera, Delphacidae), interspecific and geographic variation in acoustic behaviour // Zeitschrift Tierpsychol. Vol.58. No.1. P.31-52.

Emelyanov A.F. 2008. New species of the genus Peltonotellus Puton from Kazakhstan, Middle and Central Asia // Tethys Entomological Research. Vol.16. P.5-12.

Emelyanov A.F. 2015. [Planthoppers of the family Cixiidae of Russia and adjacent territories]. St.-Petersburg-Moscow: KMK Scientific Press. 253 pp. (Keys to species of the fauna of Russia published by Zoological Institute of Russian Academy of Sciences. Vol.177). [in Russian]

Emelyanov A.F., Tishechkin D.Y. 2012. Contributions to the study of the genus Reptalus Emeljanov, 1971 (Homoptera: Auchenorrhyncha: Cixiidae) of Western Tien Shan Mountains // Russian Entomol. J. Vol.21. No.3. P.309-314.
Gillham M.C., de Vrijer P.W.F. 1995. Patterns of variation in the acoustic calling signals of Chloriona planthoppers (Homoptera: Delphacidae) coexisting on the common reed Phragmites australis // Biol. J. Linnean Society. Vol.54. P.245-269.

de Groot M., Derlink M., Pavlovčič M., Prešern J., Čokl A., VirantDoberlet M. 2012. Duetting behaviour in a leafhopper Aphrodes makarovi (Hemiptera: Cicadellidae)// J. Insect Behavior. Vol.25. P.419-440.

Hoch H., Howarth F.G. 1993. Evolutionary dynamics of behavioural divergence among populations of the Hawaiian cave-dwelling planthopper Oliarus polyphemus (Homoptera: Fulgoroidea: Cixiidae) // Pacific Sci. Vol.47. No.4. P.303-318.

Hoch H., Mühlethaler R., Wachmann E., Stelbrink B., Wessel A. 2011. Celebenna thomarosa gen. n., sp. n. (Hemiptera: Fulgoromorpha: Cixiidae: Bennini) from Sulawesi, with notes on its ecology and behaviour // Deutsche Entomologische Zeitschrift. Bd.58. No.2. P.241-250.

Hoch H., Mühlethaler R., Wessel A. 2013. Acoustic communication in the subtroglophile planthopper Trigonocranus emmeae Fieber, 1876 (Hemiptera: Fulgoromorpha: Cixiidae: Oecleini) // Acta Musei Moraviae, Scientiae Biologicae (Brno). Vol.98. No.2. P.155-162.

Hoch H., Wessel A. 2006. Communication by substrate-borne vibrations in cave planthoppers // S. Drosopoulos, M.F. Claridge (eds.). Insect sounds and communication. Physiology, behaviour, ecology and evolution. Boca Raton, London, New York: CRC Press, Taylor and Francis Group. P.187-198.

Howarth F.G., Hoch H., Asche M. 1990. Duets in darkness: speciesspecific substrate-born vibration produced by cave-adapted cixiid planthoppers in Hawaii (Homoptera Fulgoroidea) // Mémoires de Biospéleologie. T.17. P.77-80.

Ichikawa T. \& Ishii S. 1974. Mating signal of the brown planthopper Nilaparvata lugens (Stål) (Homoptera: Delphacidae): vibration of the substrate // Applied Entomol. Zool. Vol.9. No.3. P.196198.

Ichikawa T. 1976. Mutual communication by substrate vibration in the mating behaviour of planthoppers (Homoptera, Delphacidae) // Appl. Entomol. Zool. Vol.11. No.1. P.8-23.

Ichikawa T. 1982. Density-related changes in male-male competition behaviour in the rice brown planthopper, Nilaparvata lugens (Stål) (Homoptera: Delphacidae) // Appl. Entomol. Zool. Vol.17. No.4. P.439-452.

Kunz G., Bullerdiek D., Hoch H., Holzinger W., Mühlethaler R., Wessel A. 2014. Courtship behaviour and vibrational communication of the planthopper Apartus michalki (Wagner, 1948) (Hemiptera: Fulgoromorpha: Cixiidae)// Cicadina. Vol.14 P.5563.

Mazzoni V., Lucchi A., Ioriatti C., Virant-Doberlet M., Anfora G. 2010. Mating behavior of Hyalesthes obsoletus (Hemiptera: Cixiidae) // Ann. Entomol. Soc. America. Vol.103. No.5. P.813822 .

Picciau L., Hoch H., Asche M., Tedeschi R., Alma A. 2016. The genus Cixius Latreille, 1804 (Hemiptera, Fulgoromorpha, Cixiidae) in Lebanon with the description of two new species // Zootaxa. Vol.4093. No.1. P.85-102.

Riede K. 1996. Diversity of sound-producing insects in a Bornean lowland rain forest // Tropical Rainforest Research. Kluwer Acad. Publ., Netherlands. P.77-84.

Strübing H. 1977. Lauterzeugung oder Substratvibration als Kommunikationsmittel bei Kleinzikaden? (diskutiert am Beispiel von Dictyophara europaea - Homoptera-Cicadina: Fulgoroidea) // Zoologische Beitr. Neue Folge. Bd.23. H.2. S.324332 .

Strübing H., Rollenhagen T. 1988. Ein neues Aufnehmersystem für Vibrationssignale und seine Anwendung auf Beispiele aus der Familie Delphacidae (Homoptera-Cicadina) // Zool. Jb., Physiol. Vol.92. S.245-268.

Tishechkin D.Yu. 1997. [Calling signals in males of Cixiidae (Homoptera, Cicadinea) compared with acoustic signals of some other Fulgoroidea (Homoptera, Cicadinea, Fulgoroidea)] // Zoologicheskiy Zhurnal. Vol.76. No.9. P.1016-1024 [in Russian, with English summary]. English translation: Entomological Review. 1997. Vol.77. No.8. P.1070-1077. 
Tishechkin D.Yu. 1998. [Acoustic signals of Issidae (Homoptera, Cicadinea, Fulgoroidea) compared with signals of some other Fulgoroidea with notes on taxonomic status of the subfamily Caliscelinae] // Zoologicheskiy Zhurnal.Vol.77. No.11. P.12571265 [in Russian with English summary]. English translation: Entomological Review. 1998. Vol.78. No.7. P.884-892.

Tishechkin D.Y. 2003. Vibrational communication in Cercopoidea and Fulgoroidea (Homoptera: Cicadina) with notes on classification of higher taxa // Russian Entomol. J. Vol.12. No.2. P.129-181.

Tishechkin D.Yu. 2008. On the similarity of temporal pattern of vibrational calling signals in different species of Fulgoroidea (Homoptera: Auchenorrhyncha) // Russian Entomol. J. Vol.17. No.4. P.343-351.

Tishechkin D.Yu. 2010. Acoustic signals in the communities of Bryodemini (Orthoptera: Acrididae: Oedipodinae): segregation of communication channels through the temporal divergence of acoustic activity peaks and the emergence of the dusk chorus // Russian Entomol. J. Vol.19. No.4. P.257-265.
Virant-Doberlet M., Žežlina I. 2007. Vibrational communication of Metcalfa pruinosa (Hemiptera: Fulgoroidea: Flatidae) // Ann. Entomol. Soc. America. Vol.100. No.1. P.73-82.

Vrijer P.W.F. de. 1984. Variability in calling signals of the planthopper Javesella pellucida (F.) (Homoptera, Delphacidae) in relation to temperature, and consequences for species recognition during distant communication // Netherlands J. Zool. Vol.34. No.3. P.388-406.

Vrijer P.W.F., de. 1986. Species distinctiveness and variability of acoustic calling signals in the planthopper genus Javesella (Homoptera, Delphacidae) // Netherlands J. Zool. Vol.36. No.1. P.162-175.

Winter A.J., de, Rollenhagen T. 1990. The importance of male and female acoustic behaviour for reproductive isolation in Ribautodelphax planthoppers (Homoptera: Delphacidae) // Biol. J. Linnean Society. Vol.40. P.191-206.

Wolda H. 1993. Diel and seasonal patterns of mating calls in some Neotropical Cicadas. Acoustic interference? // Proc. Koninklijke Nederlandse Akademie van Wetenschappen. Vol.96. No.3. P.369-381. 